\title{
Phosphate Rocks: A Review of Sedimentary and Igneous Occurrences in Morocco
}

\author{
Radouan El Bamiki ${ }^{1}$ D, Otmane Raji ${ }^{1, *}$, Muhammad Ouabid ${ }^{1}$ (D), Abdellatif Elghali ${ }^{1, *(D)}$, \\ Oussama Khadiri Yazami ${ }^{2}$ and Jean-Louis Bodinier 1,3
}

1 Geology and Sustainable Mining, Mohammed VI Polytechnic University, Benguerir 43150, Morocco; radouan.elbamiki@um6p.ma (R.E.B.); muhammad.ouabid@um6p.ma (M.O.); JeanLouis.Bodinier@um6p.ma (J.-L.B.)

2 OCP, Strategic Development Department, Sustainability \& Green Industrial Development, Avenue Hassan II, Khouribga 25000, Morocco; o.khadiriyazami@ocpgroup.ma

3 Geosciences Montpellier, Université de Montpellier \& CNRS, 30095 Montpellier, France

* Correspondence: otmane.raji@um6p.ma (O.R.); abdellatif.elghali@um6p.ma (A.E.)

Citation: El Bamiki, R.; Raji, O.; Ouabid, M.; Elghali, A.; Khadiri Yazami, O.; Bodinier, J.-L. Phosphate Rocks: A Review of Sedimentary and Igneous Occurrences in Morocco. Minerals 2021, 11, 1137. https:/ / doi.org/10.3390/min11101137

Academic Editor: Nicholas E. Pingitore

Received: 1 September 2021

Accepted: 13 October 2021

Published: 16 October 2021

Publisher's Note: MDPI stays neutral with regard to jurisdictional claims in published maps and institutional affiliations.

Copyright: (c) 2021 by the authors. Licensee MDPI, Basel, Switzerland. This article is an open access article distributed under the terms and conditions of the Creative Commons Attribution (CC BY) license (https:/ / creativecommons.org/licenses/by/ $4.0 /)$.

\begin{abstract}
Phosphate rocks are a vital resource for world food supply and security. They are the primary raw material for phosphoric acid and fertilizers used in agriculture, and are increasingly considered to be a potential source of rare earth elements. Phosphate rocks occur either as sedimentary deposits or igneous ores associated with alkaline rocks. In both cases, the genesis of high-grade phosphate rocks results from complex concentration mechanisms involving several (bio)geochemical processes. Some of these ore-forming processes remain poorly understood and subject to scientific debate. Morocco holds the world's largest deposits of sedimentary phosphate rocks, and also possesses several alkaline complexes with the potential to bear igneous phosphate ores that are still largely underexplored. This paper summarizes the main geological features and driving processes of sedimentary and igneous phosphates, and discusses their global reserve/resource situation. It also provides a comprehensive review of the published data and information on Moroccan sedimentary and igneous phosphates. It reveals significant knowledge gaps and a lack of data, inter alia, regarding the geochemistry of phosphates and basin-scale correlations. Owing to the unique situation of Moroccan phosphates on the global market, they clearly deserve more thorough studies that may, in turn, help to constrain future resources and/or reserves, and answer outstanding questions on the genesis of phosphates.
\end{abstract}

Keywords: sedimentary phosphate; igneous phosphate; phosphate resources; phosphogenesis; Morocco

\section{Introduction}

Phosphate rocks are by far the most important phosphorus-bearing raw material used in the fertilizer industry. They are the primary source of phosphorus $(\mathrm{P})$, which is an essential element for agriculture and various industrial applications (e.g., animal feed, cosmetics, and electronics) [1,2]. Phosphate rocks are also likely to host significant amounts of rare earth elements (REE), making them a potential REE resource given their production volume all over the world [3,4]. Similarly, phosphate rocks are also considered to be an unconventional source of uranium, especially in certain deposits, where it can reach high concentrations [5]. Other elements-such as cadmium, radium, and thorium, which could also be enriched in certain phosphate rocks-are currently weighing heavily on their production and transformation [6,7]. Phosphorus in phosphate rocks is always combined with other elements in the form of phosphate minerals, of which the most common and widely distributed belong to the apatite group [8]. Ensuring a stable supply of phosphate is among the most challenging issues facing humanity, and requires proactive strategies including the recycling of phosphate mining and processing wastes, in addition to the 
exploration of new potential phosphate ore resources $[9,10]$. Sedimentary phosphorites of marine origin are currently the primary raw material for phosphate industries, and account for a significant proportion of the world's phosphate rock production $(\simeq 90 \%)$ [11]. Igneous phosphate rocks account for $\sim 10 \%$, and the rest comes from residual and guano-type sedimentary deposits $[2,12]$. Both sources (igneous and sedimentary rocks) offer some advantages and drawbacks in terms of their chemical quality, geographical distribution, and exploitability [2].

In addition to their economic value, phosphate rocks are of high scientific value. Sedimentary phosphates provide valuable information on the ecology and chemistry of the world's past oceans [2,13]. Indeed, their genesis, accumulation, and preservation require specific paleo-environmental conditions, and involve complex biogeochemical processes during early diagenesis [2]. In addition, the link between the phosphorus cycle and the other biogeochemical cycles (e.g., $\mathrm{C}$ and $\mathrm{N}$ ) assigns the formation of phosphate rocks (phosphogenesis) an important role in the Earth's climate regulation, as well as the regulation of nitrogen and levels of atmospheric oxygen over geological timescales [13-15]. In this way, several models have been proposed to explain phosphogenesis and its seemingly discontinuous character over time [13]. On the other hand, the study of igneous apatite can provide much information related to the mechanisms of magma evolution and alkaline rock formation [16].

The Moroccan sedimentary phosphate deposits are remarkable in the world in terms of their extent and available resources (more than 70\% of the world's phosphate reserves) [17] Moroccan sedimentary phosphate rocks belong to the upper Cretaceous to lower Eocene stratigraphic interval. They outcrop in several sedimentary basins of different surface area and content [18]. This discontinuous geographical character reflects important paleointeractions with the local and the regional geodynamic context, which continues to be the subject of several controversial hypotheses [18]. These Moroccan phosphate rocks represent a unique case study to understand all of the paleo-processes involved in phosphogenesis. Indeed, the questions of how they were formed and how they have evolved over time have both a scientific and an international heritage value. Through their importance on the spatial and temporal levels, Moroccan phosphates could deliver crucial information on the paleoceanographic and paleoclimatic controls of the temporal and geographic distribution of phosphorites. Their study could also answer unresolved questions about, phosphogenesis, among others, and provide new insights on the relationship between phosphorite formation and the major biogeochemical cycles, such as the nitrogen and carbon cycles. In addition to sedimentary phosphates, Morocco hosts several carbonatite and carbonatite-alkaline complexes that could be associated with potential resources of igneous phosphate and critical metals [19-23].

To date, several studies have focused on the geological, mineralogical, and geochemical aspects of Moroccan phosphates. However, these studies fall short of the enormous research potential that these resources offer, and several questions remain unanswered. The main objective of this review paper is to summarize the current state of the art and the available knowledge on these phosphates through a review of what has been achieved so far. Through this review, Moroccan phosphates will be also positioned in the context of regional and international research on phosphate rocks.

\section{Key Features of Sedimentary and Igneous Phosphate Rocks \\ 2.1. Marine Sedimentary Phosphate Deposits}

Marine sedimentary phosphates are made up of a wide variety of phosphate particles, or "phosclasts", which can be divided into (1) skeletal grains (bioclasts, shark teeth, and bone fragments) and (2) non-skeletal grains (peloids, coprolites, aggregates, or composite grains) [24]. These phosphate particles coexist with other non-phosphatic phases such as quartz, calcite, dolomite, and clay minerals [24]. Other non-apatitic phosphate minerals are generally secondary ferrous and aluminous minerals resulting from the alteration of primary phosphates [25]. The main phosphate minerals are carbonate fluorapatite (CFA), 
formerly known as francolite [26,27]. Francolite is highly susceptible to a wide range of substitutions in various positions [27]. The fundamental substitution of $\mathrm{CO}_{3}^{-2}$ for $\mathrm{PO}_{4}{ }^{-3}$ in $0 \sim 25 \%$ of phosphate sites takes place at a $1: 1$ ratio. Substitution of $\mathrm{Na}+$ and $\mathrm{Mg}^{+}$for $\mathrm{Ca}^{2+}$ is also significant to preserve the electroneutrality of the francolite structure [27]. These substitutions, which generally reflect the composition of the solution from which they are formed, can lead to a change in chemical composition over time [27]. Dahllite (carbonate hydroxyapatite) is also found in some marine phosphate rocks. This poorly crystallized, non-stoichiometric mineral with a fibrous texture can be recognized as a "biological apatite" [28].

The majority of marine sedimentary phosphates are the result of interaction between complex biogeochemical processes that occur under particular environmental conditions (Figure 1) $[2,29,30]$. Continental margins and epeiric seas seem to be the most favorable locations for the accumulation of phosphate deposits [2,13,31]. They occur at depths varying between 100 and $500 \mathrm{~m}$, with a limited supply of terrigenous and carbonate detritus, which corresponds to a phosphogenic window [2,13,25,31]. In these environments, upwelling currents play an essential role in lifting phosphorus-rich deep water to the surface, triggering significant biological productivity $[1,2,13]$. A shift from suboxic to sulfidic conditions seems to coincide with the highest rate of apatite precipitation [32]. For its part, the biological activity promotes the establishment of phosphogenesis conditions via the accumulation of phosphorus from seawater and its recycling in sediments through the degradation of organic matter [31]. Once delivered to the sediment-water interface, this organic phosphorus is subjected to further microbial activity that controls its transformation into inorganic forms [31]. At this stage, most of the phosphorus produced by microbial respiration or "mineralization" processes is returned to seawater (Figure 1). However, the so-called "polyphosphate pumping" processes related to the activity of polyphosphateaccumulating sulfur bacteria appear to be a driver of phosphate sequestration during the transport of phosphorus from the water interface to underlying sediments [31,33]. Indeed, it was highlighted in modern sediments that these bacteria accumulate phosphate and store it as polyphosphate inclusions under oxic conditions. Once the conditions become anoxic, they undertake the hydrolysis of the polyphosphates to produce energy, releasing large amounts of orthophosphate into pore waters. This triggers the precipitation of carbonate fluorapatite (CFA) precursors after reaching the supersaturation conditions [33,34]. Another important source of phosphate in pore waters is iron redox pumping (Figure 1). In this case, the sorbed phosphate is released within the sediment from Fe oxyhydroxides when these phases are buried in anoxic zones [31,34,35]. Iron oxyhydroxides also act as catalysts of polyphosphate hydrolysis and the precipitation of calcium phosphate minerals [36]. In addition to involvement in sedimentary phosphogenesis, there are several forms through which iron is linked with phosphatic deposits. The iron phosphates are considered to be a significant long-term sink for phosphorus in marine sediments [37]. Indeed, the presence of the $\mathrm{Fe}(\mathrm{II})-\mathrm{Fe}(\mathrm{III})$ hydroxychloride crystals in the sediment can significantly enhance the P sequestration under anoxic conditions by forming iron-phosphate complexes and slowing down their oxidation and transformation, e.g., [38,39]. The phosphatic iron ores could be of economic interest; such is the case of the phosphatic ferromanganese crust deposits, which are increasingly regarded as potential sources of phosphorus and critical metals $[40,41]$. Their phosphatization is associated with the replacement of carbonate and preferential replacement of Fe oxyhydroxide relative to Mn oxide [42]. High-phosphorus ooidal iron ores are another example in which iron is correlated with phosphorus and rare earth elements. Recent works suggest a potential geological connection between large igneous provinces (LIPs), upwelling, marine hypoxia, rifting, and their formation $[43,44]$. 


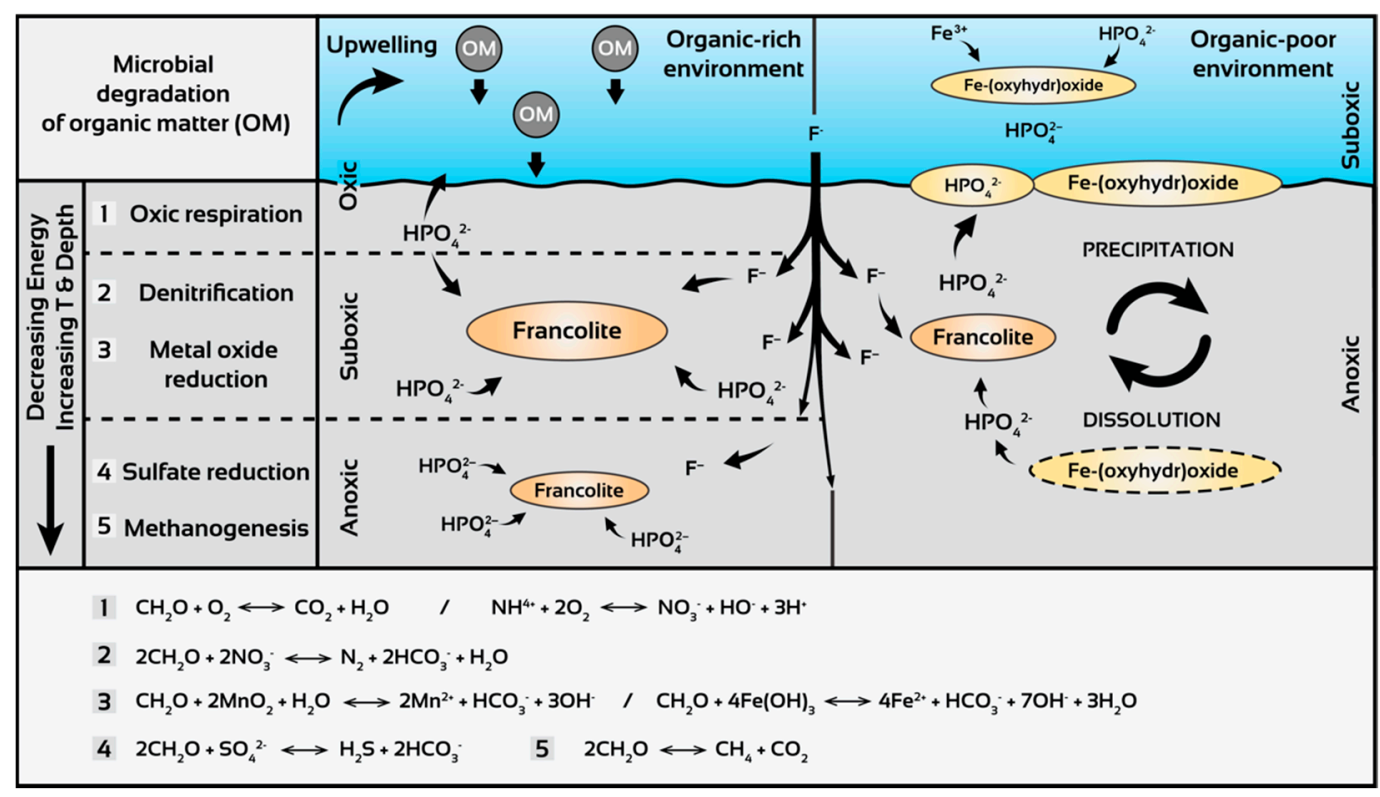

Figure 1. Different phosphogenic processes. In upwelling environments, organic matter (OM) is microbially degraded through a series of chemical reactions that lead to the concentration of dissolved phosphate in pore water, facilitating the authigenic precipitation of carbonate fluorapatite. In organic-poor environments, Fe redox pumping is the primary process leading to high concentrations of phosphate in pore water via cyclical adsorption and release of phosphate from Fe oxyhydroxides. (Modified from Pufahl and Groat (2017), and references therein [2]).

In contrast to iron, $\mathrm{Mg}^{2+}$ ions are known to inhibit the precipitation of carbonate fluorapatite, which means that pore waters should be depleted of $\mathrm{Mg}^{2+}$ to create favorable conditions [29]. Similarly, the phosphate sorption is controlled by dissolved silica ( $\mathrm{Si}$ ), knowing that its inhibitory effect could also depend on magnesium and calcium concentrations $[45,46]$. Either way, it should be noted that all of the redox-controlled microbial and abiotic CFA precipitation processes cited above also account for a number of other authigenic mineral precipitations, including glauconite, pyrite, and dolomite [2,47]. The newly formed carbonate fluorapatite is concentrated in the form of phosphatic particles and laminae, which can be rapidly buried, giving way to another cycle of phosphogenesis. The repetition of this cycle over time allows the formation of pristine laminated sedimentary phosphates [13,48]; their $\mathrm{P}_{2} \mathrm{O}_{5}$ content rarely exceeds $10 \%$, and is often sub-economic, except for some of them that may be beneficiated to increase their grade to economically viable concentrations [2]. The transformation of these pristine sedimentary phosphates into naturally enriched phosphorites occurs under specific post-depositional conditions [1,2,13]. A first possible scenario is an in situ enrichment process via winnowing. This mechanical process, induced by storm and button currents, consists of a substantial removal of fine sediment particles, leaving behind phosphatic grains and taking advantage of their higher specific density with respect to the average sediment $[13,47]$. The recurrence and amalgamation of winnowing episodes, coupled with restricted detrital inputs, result in the formation of economic phosphate accumulations over large areas [2,24]. When transported from their initial formation sites to new sedimentary environments during transgressive or regressive periods, the primary phosphatic particles result in an allochthonous phosphate [2]. Indeed, basinward transport of phosphatic particles may lead to their distal accumulation as turbiditic layers with typical features of gravity flow sediments. On the other hand, landward transport-mainly during transgressive events-transfers substantial amounts of phosphate towards the proximal parts, where they can be reworked, enriched, and preserved, or even diluted and mixed with the detrital material delivered from the hinterland [2,49].

Based on either the outcrop descriptions, petrography, chemical composition, or their combination, several classifications have been proposed for marine sedimentary phosphate rocks [2]. The classification proposed by Föllmi (1996) [13] is the simplest and 
most practical due to its applicability to large marine phosphate types of all ages and from various depositional environments. It recognizes two types of broad lithofacies (Figure 2):

(i) Pristine phosphate, corresponding to the authigenic facies as deposited originally without any subsequent reworking or transport. This lithofacies usually takes the form of finely laminated sediment with disseminated authigenic francolite. It contains high content of organic matter and low phosphate concentrations, ranging from 2 to 10 wt. $\% \mathrm{P}_{2} \mathrm{O}_{5}$;

(ii) Reworked phosphate or Granular phosphate results from reworking and re-sedimentation of the primary phosphate under high-energy conditions induced by storm waves and currents. These reworking events can occur in situ or at different parts of the depositional system, allowing the formation of a densely packed and cleaned phosphate with high $\mathrm{P}_{2} \mathrm{O}_{5}$ content (up to 35 wt.\%).

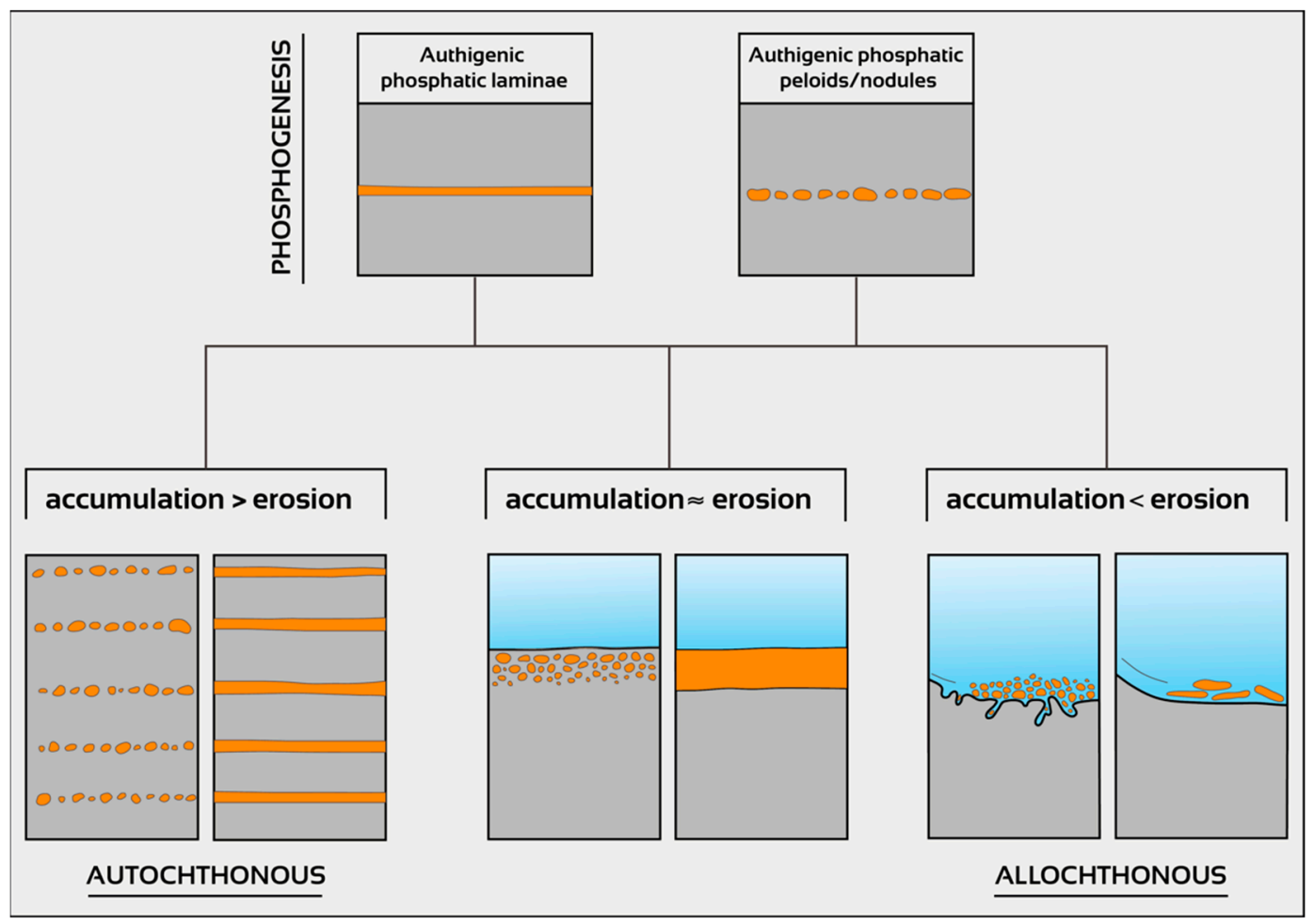

Figure 2. Genetic phosphate classification: pristine vs. reworked phosphate (based on [13]).

\subsection{Igneous Phosphates}

The igneous apatite (F-rich) is the omnipresent accessory mineral found in almost all igneous rocks, from mafic to felsic, although $0.11 \mathrm{vol} \%$ of the rock is in the more normal range [50]. However, some peculiar igneous systems can often lead to economically valuable accumulations of apatite (concentrations $>3-5 \mathrm{vol} \%$ of the rock) $[2,50,51]$. These igneous phosphate accumulations are mainly associated with carbonatite/alkaline systems (dominant) and/or some anorthositic magmas (Table 1) [52,53]. The Khibina and Kovdor alkaline-carbonatite complexes in the Kola Peninsula (Russia), where phosphate rocks consist mainly either of apatite-nepheline-rich rocks (Khibina) or magnetite-apatite-rich ultramafic plutonic rocks (phoscorites, Kovdor), form the world's largest igneous phosphate deposit [53-57]. In addition to Russia, other important carbonatite/alkaline-related phosphate ores have been reported and mined in, e.g., Palabora in South Africa, Siilinjärvi in Finland, Jacupiranga in Brazil, and Dorowa in Zimbabwe-mainly to produce fertilizers $[2,53,58]$. Table 1 summarizes the main characteristics of the important igneous phosphate deposits worldwide, showing that $\mathrm{P}_{2} \mathrm{O}_{5}$ contents are variable, and range between 3 and $38 \%$. In contrast to sedimentary phosphorites, the igneous phosphate ores 
are more economically important, since they offer high-quality phosphates with minimal concentrations of undesirable contaminants (e.g., Cd, As, Pb, Si, Al). They can be associated with economic concentrations of some strategic elements, including rare earth elements, niobium, copper, titanium, zirconium, uranium, vermiculite, and iron (Table 1 , Figure 3) $[53,59]$. Currently, the world's largest REE deposits are primarily associated with carbonatite-alkaline complexes, e.g., Bayan Obo in China [60,61] and Mountain Pass, USA [62]. Table 1 also gives a review of the available age determinations of the major worldwide carbonatite/alkaline-related phosphate ores, which were formed from the Archean to current times (Cenozoic).

Table 1. Principal worldwide igneous phosphate ores. Data from [58,63-67] and references therein.

\begin{tabular}{|c|c|c|c|c|c|}
\hline Country & Ore & Age & $\begin{array}{c}\mathrm{P}_{2} \mathrm{O}_{5} \\
\text { Content }(\%)\end{array}$ & $\begin{array}{l}\text { Major Associated } \\
\text { Commodity }\end{array}$ & Rock in Deposit \\
\hline \multirow[t]{2}{*}{ Russia } & $\begin{array}{c}\text { Khibina } \\
\text { (Kola Peninsula) }\end{array}$ & $\begin{array}{c}\text { Devonian } \\
(385-360 \mathrm{Ma})\end{array}$ & 15 & Nepheline (Al) & $\begin{array}{c}\text { Carbonatite, eruptive breccia, } \\
\text { foyaite, ijolite, melteigite, } \\
\text { nepheline syenite, } \\
\text { phoscorite, urtite }\end{array}$ \\
\hline & $\begin{array}{c}\text { Kovdor } \\
\text { (Kola Peninsula) }\end{array}$ & $\begin{array}{c}\text { Devonian } \\
(385-360 \mathrm{Ma})\end{array}$ & $6-7$ & $\begin{array}{l}\text { Magnetite }(\mathrm{Fe}), \\
\text { vermiculite, } \\
\text { baddeleyite }(\mathrm{Zr})\end{array}$ & $\begin{array}{c}\text { Carbonatite, dunite, ijolite, } \\
\text { melteigite, phoskorite, pyroxenite }\end{array}$ \\
\hline \multirow[t]{2}{*}{ South Africa } & Palabora & $\begin{array}{l}\text { Paleoproterozoic } \\
\quad(\sim 2 \mathrm{Ga})\end{array}$ & $7-9$ & $\begin{array}{c}\text { Vermiculite, } \\
\text { chalcopyrite }(\mathrm{Cu}), \\
\text { magnetite }(\mathrm{Fe}), \\
\text { thorite }(\mathrm{U}), \\
\text { baddeleyite }(\mathrm{Zr})\end{array}$ & $\begin{array}{c}\text { Carbonatite, phoscorite, } \\
\text { micaceous pyroxenite, pyroxene- } \\
\text { phlogopite-apatite pegmatoid }\end{array}$ \\
\hline & Glenover & $\begin{array}{l}\text { Upper } \\
\text { Proterozoic } \\
(\sim 1 \mathrm{Ga})\end{array}$ & $25-29$ & & $\begin{array}{l}\text { Apatite-hematite breccia, } \\
\text { carbonatite, pyroxenite }\end{array}$ \\
\hline \multirow{8}{*}{ Brazil } & Jacupiranga & $\begin{array}{l}\text { Jurassic- } \\
\text { Cretaceous } \\
(161-125 \mathrm{Ma})\end{array}$ & $\sim 5$ & Lime (calcite) & $\begin{array}{l}\text { Carbonatite, ijolite, peridotite, } \\
\text { jacupirangite, nepheline syenite }\end{array}$ \\
\hline & Araxá & $\begin{array}{l}\text { Cretaceous } \\
(\sim 87 \mathrm{Ma})\end{array}$ & 15 & Pyrochlore $(\mathrm{Nb})$ & $\begin{array}{l}\text { Carbonatite, glimmerite, } \\
\text { lamprophyre, phoscorite }\end{array}$ \\
\hline & Catalão I & $\begin{array}{l}\text { Cretaceous } \\
(\sim 83 \mathrm{Ma})\end{array}$ & $5-17$ & Pyrochlore $(\mathrm{Nb})$, $\mathrm{Ti}$ & $\begin{array}{l}\text { Carbonatite, dunite, } \\
\text { glimmerite, pyroxenite }\end{array}$ \\
\hline & Tapira & $\begin{array}{l}\text { Cretaceous } \\
(\sim 70 \mathrm{Ma})\end{array}$ & $\sim 8$ & Anatase (Ti) & $\begin{array}{c}\text { Carbonatite, dunite, bebedourite, } \\
\text { jacupirangite, peridotite, syenite, } \\
\text { silexite, trachyte, tuff }\end{array}$ \\
\hline & Angico dos Dias & $\begin{array}{l}\text { Paleoproterozoic } \\
\text { (2 Ga) }\end{array}$ & $\sim 15$ & & Carbonatite, syenite, pyroxenite \\
\hline & Anitápolis & $\begin{array}{l}\text { Cretaceous } \\
(131-104 \mathrm{Ma})\end{array}$ & $6-35$ & & $\begin{array}{c}\text { Ijolite, biotite pyroxenite, } \\
\text { nepheline syenite, carbonatite }\end{array}$ \\
\hline & Ipanema & $\begin{array}{l}\text { Cretaceous } \\
(138-121 \mathrm{Ma})\end{array}$ & $\sim 7$ & & $\begin{array}{l}\text { Glimmerite, carbonatite, } \\
\text { aegirinite, syenite }\end{array}$ \\
\hline & Miacuru & $\begin{array}{l}\text { Ediacaran } \\
(\sim 589 \mathrm{Ma})\end{array}$ & 15 & & $\begin{array}{l}\text { Pyroxenite, syenite, glimmerite, } \\
\text { carbonatite }\end{array}$ \\
\hline \multirow{2}{*}{ Finland } & Siilinjärvi & $\begin{array}{l}\text { Archean } \\
(\sim 2.6 \mathrm{Ga})\end{array}$ & $>3.5$ & $\begin{array}{l}\text { Lime (calcite), } \\
\text { phlogopite }\end{array}$ & Glimmerite, carbonatite, fenite \\
\hline & Sokli & $\begin{array}{c}\text { Devonian } \\
(410-362 \mathrm{Ma})\end{array}$ & $\sim 16$ & & Carbonatite, phoscorite, fenite \\
\hline \multirow[t]{2}{*}{ Uganda } & Bukusu & $\begin{array}{l}\text { Cenozoic } \\
(\sim 40 \mathrm{Ma})\end{array}$ & $\sim 15$ & & $\begin{array}{c}\text { Carbonatite, melteigite, ijolite, } \\
\text { pyroxenite, syenite }\end{array}$ \\
\hline & Sukulu & $\begin{array}{l}\text { Cenozoic } \\
(\sim 40 \mathrm{Ma})\end{array}$ & $11-13$ & $\begin{array}{l}\text { Magnetite }(\mathrm{Fe}) \text {, } \\
\text { pyrochlore }(\mathrm{Nb})\end{array}$ & Carbonatite, syenite \\
\hline
\end{tabular}


Table 1. Cont.

\begin{tabular}{|c|c|c|c|c|c|}
\hline Country & Ore & Age & $\begin{array}{c}\mathrm{P}_{2} \mathrm{O}_{5} \\
\text { Content (\%) }\end{array}$ & $\begin{array}{l}\text { Major Associated } \\
\text { Commodity }\end{array}$ & Rock in Deposit \\
\hline Zimbabwe & Dorowa & Mesozoic & $5-7$ & Magnetite (Fe) & $\begin{array}{l}\text { Carbonatite, ijolite, syenite, } \\
\text { fenite, nephelinite }\end{array}$ \\
\hline Sri Lanka & Eppawala & $\begin{array}{l}\text { Ediacaran } \\
(\sim 550 \mathrm{Ma})\end{array}$ & 38 & & Carbonatite \\
\hline \multirow[t]{3}{*}{ Canada } & $\begin{array}{l}\text { Lackner Lake } \\
\text { (Ontario) }\end{array}$ & $\begin{array}{l}\text { Neoproterozoic } \\
\quad(\sim 1.1 \mathrm{Ga})\end{array}$ & $\sim 9$ & $\begin{array}{c}\text { Pyrochlore }(\mathrm{Nb}) \text {, } \\
\text { magnetite }(\mathrm{Fe}), \\
\text { REE }\end{array}$ & $\begin{array}{c}\text { Carbonatite, ijolite, } \\
\text { syenite, lamprophyre }\end{array}$ \\
\hline & Cargill (Ontario) & $\begin{array}{l}\text { Neoproterozoic } \\
\quad(\sim 1.7 \mathrm{Ga})\end{array}$ & $\sim 20$ & & Carbonatite, pyroxenite \\
\hline & $\begin{array}{l}\text { Martinson } \\
\text { (Ontario) }\end{array}$ & & $20-23$ & Pyrochlore $(\mathrm{Nb})$ & Carbonatite, ultramafic breccia \\
\hline \multirow[t]{2}{*}{ Namibia } & Ondurakorume & Cretaceous & 7 & REE, Sr, Nb & $\begin{array}{c}\text { Carbonatite, syenite, } \\
\text { volcanic breccia }\end{array}$ \\
\hline & Otjisazu & $\begin{array}{l}\text { Neoproterozoic } \\
\quad(\sim 837 \mathrm{Ma})\end{array}$ & $3-5$ & & $\begin{array}{l}\text { Carbonatite, pyroxenite, } \\
\text { syenite, fenite }\end{array}$ \\
\hline \multirow[t]{2}{*}{ Zambia } & Nkombwa Hill & $\begin{array}{l}\text { Neoproterozoic } \\
(\sim 679 \mathrm{Ma})\end{array}$ & $7-8$ & $\begin{array}{c}\text { Pyrochlore }(\mathrm{Nb}), \\
\text { REE }\end{array}$ & Carbonatite, fenite \\
\hline & Kaluwe & $\begin{array}{l}\text { Cretaceous } \\
(100-103 \mathrm{Ma})\end{array}$ & $3-5$ & & Carbonatite \\
\hline Burundi & Matongo & $\begin{array}{l}\text { Neoproterozoic } \\
\text { (739-780 Ma) }\end{array}$ & $\sim 11$ & & $\begin{array}{l}\text { Carbonatite, syenite, } \\
\text { gabbro, diorite }\end{array}$ \\
\hline
\end{tabular}

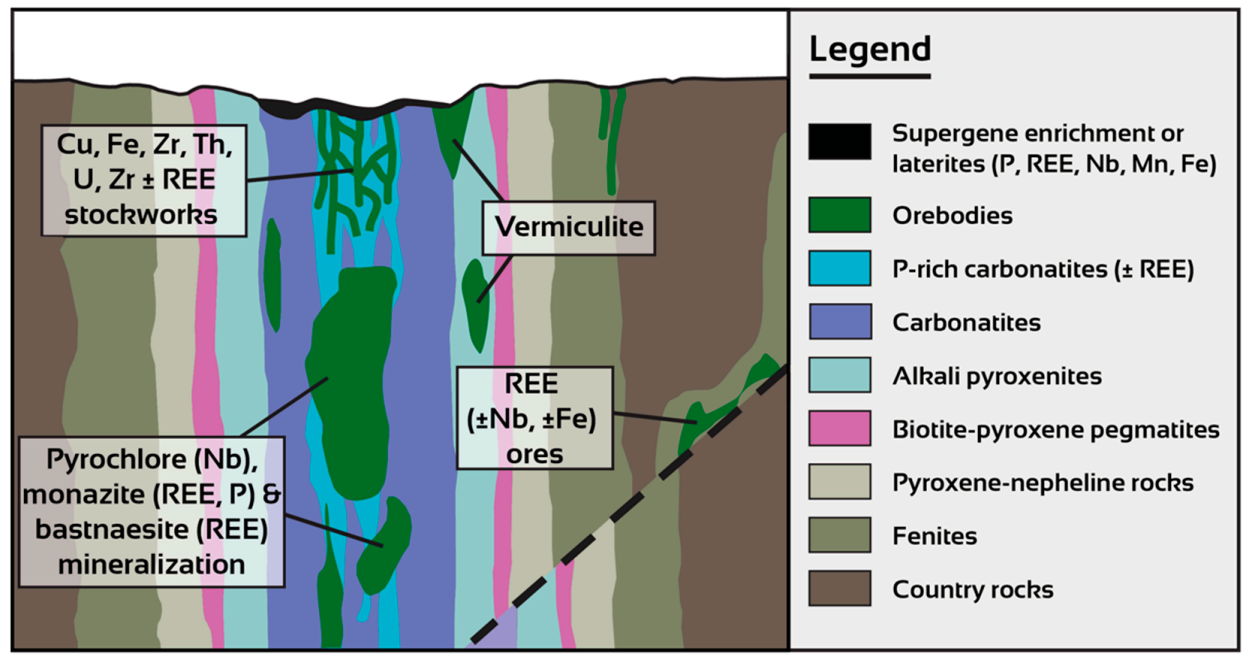

Figure 3. Geological cross-section of a hypothetical carbonatite-alkaline system and main related mineral deposits [53,59]. Not to scale.

Three major hypotheses are proposed to account for the origin of carbonatite/alkaline magmas: The first is the immiscibility of carbonated silicate magmas at crustal or mantle pressures $[68,69]$. The second hypothesis is the fractional crystallization of carbonated silicate magmas, such as olivine melilitites or kamafugites [70]. The final hypothesis is attributed to the low-degree partial melting of carbonated mantle peridotite, e.g., [69,71]. Significant phosphate accumulations are typical characteristics of these carbonatite-alkaline systems (Figure 3), where the crystal fractionation is proposed as the primary driving force in the petrogenesis of these mineralized carbonatites (Figure 3) $[54,56,64]$. However, phosphorus shows a clear preference for the carbonate melt relative to the associated silicate alkaline melt [72]. Moreover, phosphate petrogenesis involves the role of frac- 
tional crystallization and/or liquid immiscibility to separate P-rich fluids from carbonate melts $[53,54,59]$. In addition, several recent geological investigations emphasize the role of melts in the genesis of carbonatite-related ores [61,73-75], which provide constraints on the transportation of phosphates and REE/ $\mathrm{Nb}$ by hydrothermal fluids and their deposition. The role of metasomatism, including late-stage alteration, is also crucial in the ultimate understanding of these phosphate accumulations [19,47,53,72]. However, some apatite accumulations are also reported in the weathering profiles of carbonatites, and sometimes give high-grade ore deposits (e.g., Figure 3) [51,76]. The weathering of carbonatite complexes generates the replacement/decomposition of carbonatite primary minerals to form lateritic profiles with significant phosphate and $\mathrm{REE}-, \mathrm{Nb}-$, and Fe-bearing mineral accumulations (Figure 3) $[77,78]$. The higher accumulations of phosphate found in these supergene profiles could be linked to the leaching and removal of primary carbonates generating the reduction in the initial rock volume, which is enriched in more weathering-resistant mineral phases, such as non-carbonate minerals $[53,77,79]$.

\section{Moroccan Sedimentary Phosphates: A Unique Geological Heritage}

\subsection{Geological and Depositional Setting of Moroccan Sedimentary Phosphate}

The most important sedimentary phosphates in Morocco are distributed mainly over four basins: Ouled Abdoun, Ganntour, Meskala, and Oued Ed-dahab (Figure 4). However, phosphates are also reported in other sites of less economic importance: Middle Atlas, Beni Mellal, High Atlas, the Marrakesh High Atlas northern basins, Souss, and the Ouarzazate basins (Figure 4) [18]. These deposits form part of the Mediterranean (Tethyan) phosphogenic province [80]. They were deposited during the Upper Cretaceous-Paleogene period-more specifically, from the Maastrichtian to the Ypresian.

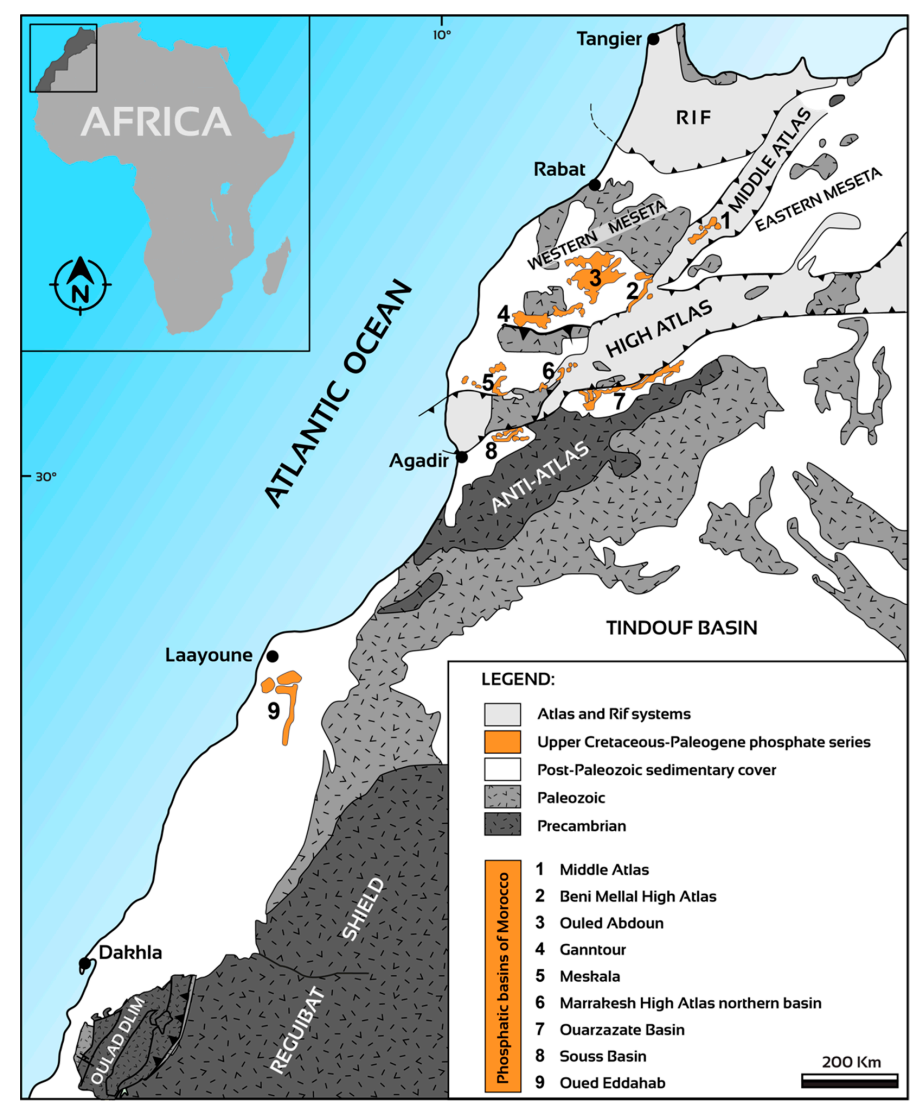

Figure 4. Simplified geological map of Morocco illustrating the distribution of phosphate accumulations in the different structural domains of Morocco (modified based on Piqué, 1994, [81]). 
The geochronology of Moroccan phosphates was determined mainly using biostratigraphic approaches, taking advantage of their remarkably rich and diversified fauna. Indeed, the study of vertebrates—specifically selachian assemblages—-helped to identify three bio-zones, namely, the Late Cretaceous (Maastrichtian), Paleocene (Danian and Thanetian), and Eocene (Ypresian and Lutetian) [82]. On the other hand, the study of dinocysts allowed the definition of reference levels for the regional correlation of the top end of the Maastrichtian [83]. Similarly, the study of pollen assemblages in the Ganntour Basin has shown that the Selandian (previously known as Montian), Thanetian, and Ypresian forms can be differentiated and correlated with the European forms, some of which can be used as stratigraphic markers [84]. Moreover, the study of dinoflagellates in the Ouled Abdoun Basin has provided markers for the Thanetian and Basal Ypresian [85]. Accordingly, the Moroccan sedimentary phosphate deposition was spread over a much more extended period compared to other deposits in the Tethyan province (Figure 5). The resultant phosphate accumulations correspond to a succession of phosphate-rich layers hosted by marine-dominated sediment bounded by under- and overlying continental sediments [86] (Figure 6). Phosphatic layers occur mainly in the form of either granular phosphate, phosphatic limestone, or phosphatic marl, and the non-phosphatic layers correspond mostly to marls, limestones, dolomites, and clays/silts (Figure 6).

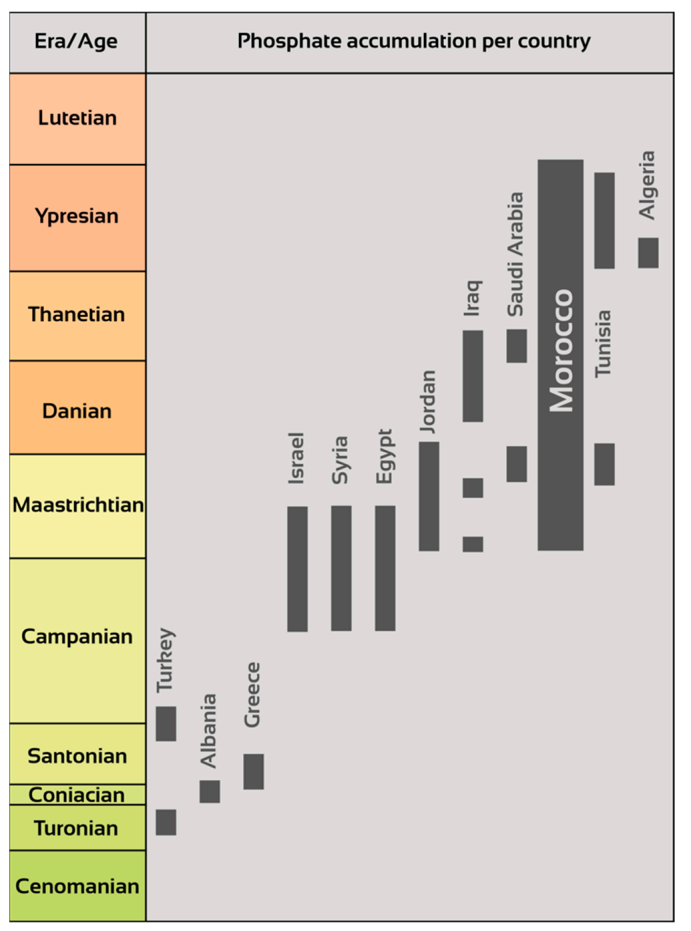

Figure 5. Stratigraphic distribution of phosphates in the Tethyan province [80].

The Ouled Abdoun Basin, also known as the Phosphate Plateau, is part of the Atlantic coastal basin, which consists of a tabular Meso-Cenozoic cover overlying a deformed Hercynian basement [87]. The phosphate series of Ouled Abdoun, spanning the MaastrichtianYpresian stratigraphic interval, shows various phosphatic facies, including phosphatic marls, phosphorus-rich sandy phosphates, and coprolitic phosphatic limestones with flint nodules [88]. The Ganntour Basin corresponds to a plateau formed by a Meso-Cenozoic sedimentary series that rests on a deformed Hercynian basement. Phosphate facies in this basin include friable granular phosphates, silty phosphates, and phosphatic limestones [89]. Phosphatic layers of economic interest in the Ouled Abdoun and Ganntour basins have been given specific nomenclature for mining purposes: $\mathrm{C}$, $\mathrm{C} 1$, and so on, from top to base, for major layers, and "sillon" for thin phosphatic layers (Figure 6). The phosphate series of 
Meskala occurs in isolated synclinal basins; it is composed of phosphatic marls shifting to porcelanites and marls, and then to fossiliferous carbonates at the top [90].

The Upper Cretaceous-Paleogene series of the High Atlas hosts unexplored phosphaterich sediments [91]. This series is a carbonate-dominated sedimentary succession organized in two second-order transgressive-regressive sedimentary systems [92,93]. These marine sediments developed between the underlying Senonian continental series and the overlying Neogene erosive continental deposits. Phosphatic facies include granular phosphate, phosphatic marls, and phosphatic sandstones and microconglomerates [18]. The Souss Basin, located at the southern edge of the High Atlas, embodies the thickest known Maastrichtian sequence in Morocco, and contains various phosphatic sediments, including phosphatic sandstones and microconglomerates.

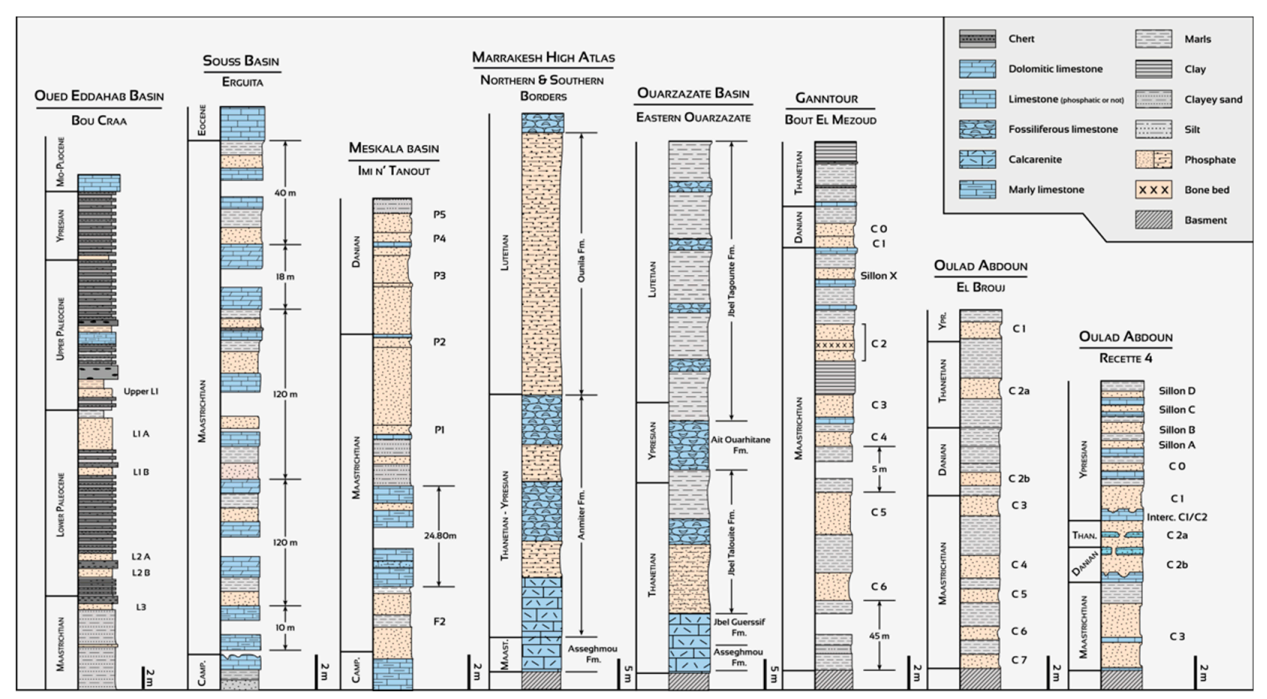

Figure 6. Stratigraphic framework of the Moroccan phosphate series in different basins. Phosphatic layers are intercalated with non-phosphatic sediments of various lithologies. Note that numbers of phosphatic layers are not equivalent in different basins-layer C2 in Ouled Abdoun is Danian-Thanetian, while layer C2 in Ganntour dates from the Upper Maastrichtian. Compiled from [94-97].

In the Moroccan Saharan domain, the Meso-Cenozoic basin of Oued Ed-dahab encompasses a Maastrichtian to Lutetian phosphate series showing three main phosphate-rich layers (L1, L2, and L3) composed of coprolitic and granular phosphate [94]. These layers are intercalated with non-phosphatic chert- and clay-dominated sediments (Figure 6).

\subsection{Mineralogical and Geochemical Signatures of Moroccan Sedimentary Phosphates}

Compared to the other phosphate deposits from the Mediterranean province, and international phosphorites, the standardized quality of mineralogical or geochemical data is very rare or even unavailable for the natural phosphate rocks from Morocco. The few published works deal with data on the geochemistry of phosphate bioconstituents rather than the bulk rock $[98,99]$. The available data on Moroccan sedimentary phosphates show that, similar to other regional phosphate rocks, they are mainly composed of francolite and associated gangue minerals (e.g., calcite, dolomite, quartz, gypsum (occasionally)) and clay minerals (e.g., smectite, illite, palygorskite, sepiolite, kaolinite). Glauconite, sulfides (mainly pyrite), iron oxides (e.g., hematite and goethite), and feldspar are also found as accessory minerals.

In terms of geochemical composition, the oxide contents are variable according to the situations and ages of the different deposits but, overall, the most naturally abundant oxides are $\mathrm{CaO}$ and $\mathrm{P}_{2} \mathrm{O}_{5}$. The average $\mathrm{CaO}$ and $\mathrm{P}_{2} \mathrm{O}_{5}$ contents are approximately $36 \pm 11 \mathrm{wt} . \%$ and $22 \pm 8 \mathrm{wt} . \%$, respectively (Table 2 ). 
Table 2. $\mathrm{CaO}$ and $\mathrm{P}_{2} \mathrm{O}_{5}$ contents in the phosphates of Ouled Abdoun according to the ages of the deposits. S.D. = standard deviation. Data from [100].

\begin{tabular}{ccccc}
\hline Age & Mean CaO Wt. $\%$ & S.D. & Mean $\mathbf{P}_{\mathbf{2}} \mathbf{O}_{\mathbf{5}} \mathbf{W t .} \%$ & S.D. \\
\hline Ypresian $(\mathrm{n}=7)$ & 36.41 & 11.65 & 22.17 & 8.05 \\
\hline Thanetian $(\mathrm{n}=4)$ & 36.50 & 6.33 & 15.83 & 2.46 \\
\hline Danian $(\mathrm{n}=5)$ & 46.04 & 6.15 & 24.26 & 6.53 \\
\hline Maastrichtian $(\mathrm{n}=14)$ & 39.90 & 7.26 & 20.89 & 5.80 \\
\hline
\end{tabular}

In certain silicified facies, average $\mathrm{SiO}_{2}$ content can reach $14 \mathrm{wt} . \%$ alongside $\mathrm{CaO}$ and $\mathrm{P}_{2} \mathrm{O}_{5}$ (Table 3). As for other worldwide phosphate deposits, some Moroccan phosphates can be relatively enriched in certain minor and trace elements, e.g., uranium (U), strontium (Sr), cadmium (Cd), and rare earth elements (REE) (Table 3 and Figure 7).

Table 3. The average composition of some samples of phosphate rocks from the Ouled Abdoun basin. Data from [88].

\begin{tabular}{|c|c|c|c|c|c|c|c|c|c|c|c|c|c|c|}
\hline & $\mathrm{SiO}_{2}$ & $\mathrm{Al}_{2} \mathrm{O}_{3}$ & $\mathrm{MgO}$ & $\mathrm{CaO}$ & $\mathrm{Fe}_{2} \mathrm{O}_{3}$ & $\mathrm{TiO}_{2}$ & $\mathrm{Na}_{2} \mathrm{O}$ & $\mathrm{K}_{2} \mathrm{O}$ & $\mathbf{P}_{2} \mathrm{O}_{5}$ & L.O.I & & & & \\
\hline Mean $(n=146)$ & 14.73 & 2.49 & 4.08 & 37.07 & 0.99 & 0.15 & 0.33 & 0.46 & 11.68 & 24.72 & & & & \\
\hline \multirow[t]{2}{*}{ S.D. $(n=146)$} & 8.59 & 1.97 & 3.84 & 9.82 & 0.82 & 0.09 & 0.18 & 0.43 & 9.12 & 8.66 & & & & \\
\hline & $\mathrm{Sr}$ & $\mathrm{Ba}$ & $\mathrm{V}$ & $\mathrm{Ni}$ & Co & $\mathrm{Cr}$ & B & $\mathrm{Mn}$ & $\mathrm{Zn}$ & $\mathrm{Ga}$ & $\mathrm{Cu}$ & $\mathrm{Pb}$ & Sn & $\mathrm{Cd}$ \\
\hline Mean $(n=146)$ & 762 & 74 & 80 & 95 & 0.27 & 181 & 8 & 36 & 158 & 0.33 & 43 & 14 & 0.32 & 9 \\
\hline S.D. $(n=146)$ & 392 & 46 & 142 & 53 & 2 & 91 & 17 & 47 & 97 & 2 & 21 & 44 & 1 & 9 \\
\hline
\end{tabular}

The Moroccan phosphates have lower values of $\Sigma$ REE compared to other examples worldwide. However, they show the same patterns with negative Ce anomalies [101]. The distribution of REE likely reflects the deposition and preservation conditions, given that the redox conditions and reworking process can severely affect the REE contents in the final phosphate rocks [101]. The phosphatic bioparticles exhibited the same distribution of REE as the natural phosphatic rocks (i.e., a negative Ce anomaly and HREE enrichment) (Figure 7). These REE patterns are similar to the REE pattern of modern oxic seawater, suggesting REE uptake by fossils from an early diagenetic pore fluid that was dominated by seawater $[98,99]$.

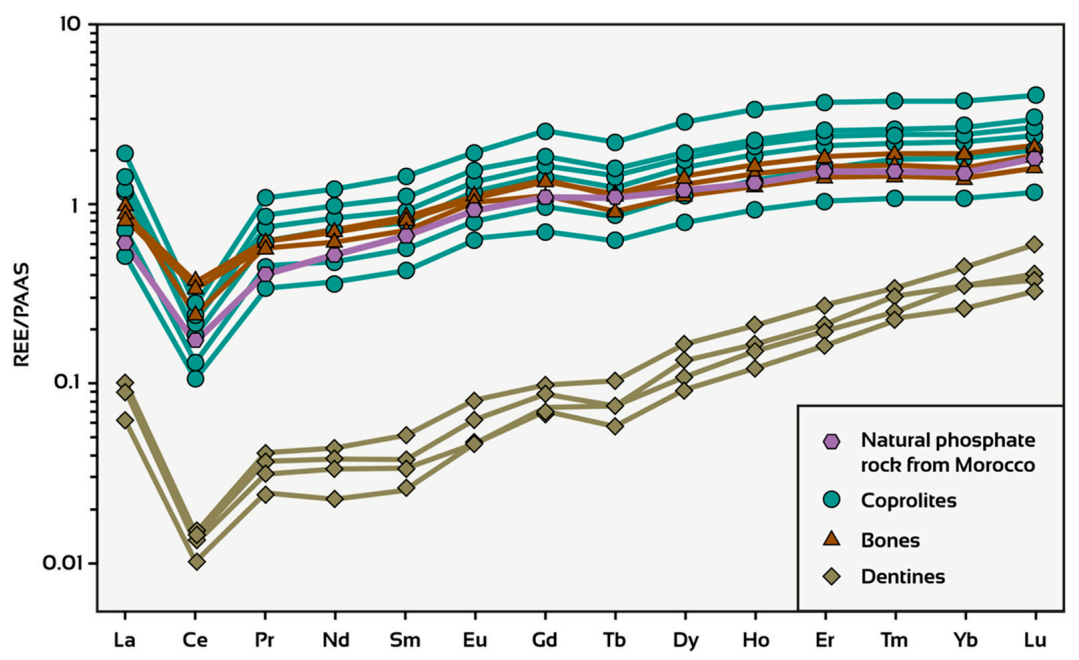

Figure 7. PAAS-normalized REE patterns for different phosphate bioparticles (coprolites, bones, and dentines) [98,99] compared to natural phosphate rock from Morocco [102]. 


\subsection{Phosphogenesis and Paleogeography of Phosphate Deposits in Morocco}

The economic phosphorites of Morocco show the characteristics of an epicontinental sea with a restricted and very shallow marine environment of formation linked to an upwelling system located on the Atlantic margin $[86,87]$. They also show a clear signature of interaction between biological and geochemical processes [86,90]. In addition, the study of the geochemical properties of the organic matter showed that phosphogenesis occurred under intermediate redox conditions [90]. These conditions favor a partial degradation of organic matter to release phosphorus into the interstitial microsystems, preventing its recycling into seawater $[86,90]$. On the other hand, the exceptional accumulation of phosphate in Morocco reflects a mechanical concentration of phosphatic elements via hydrodynamic processes as a part of a multistage post-phosphogenesis evolution of primary phosphate that involves reworking, transport, and secondary accumulation on the marine platform $[18,86-88]$. On a global scale, the concentration of phosphate in phosphate plateaus in Morocco seems to be controlled mainly by paleogeographic and eustatic forcing [103]. Nevertheless, the debate remains open in terms of the paleogeographic model for Moroccan phosphate. Four different models with contrasting trends have been proposed (Figure 8):

(i) A system of narrow gulfs separated by emerged lands (Figure 8A,B; Rehamna and Jebilet Hercynian massifs) [89]. In this paleogeographic configuration, the opening to the Atlantic would correspond to several narrow corridors [89]. For some authors, the opening to the Atlantic was through at least three distinct gulfs (Ouled AbdounGanntour, Ouarzazate-Essaouira, and Souss) [88,89].

(ii) Salvan [104] proposed a model with large openings or a combination of a large connection with the Atlantic Ocean and interconnected gulfs (Figure 8B);

(iii) An epicontinental sea in a single open expanse westward to the Atlantic, with the existence of land masses in central Morocco and within the Atlas domain (Figure 8C) [105,106];

(iv) A vast epicontinental sea (Phosphate Sea) without the presence of islands, in direct connection with the Atlantic Ocean to the west (Figure 8D) [91]. In this paleogeographic configuration, landforms did not occur during phosphogenic periods. Charrière et al. (2009) [107] suggested that the position of the paleo-coastline should be shifted to the east at the Imilchil area following the discovery of charophytes and ostracods in the Lutetian (Figure 8D). The presence of terrestrial vertebrates (dinosaurs, pterosaurs, mammals) in the northeastern parts of the Ouled Abdoun Basin suggests that this area corresponded to a proximal high-energy environment in the vicinity of the Paleozoic central massif [108]. The phosphate series at the Ganntour Basin, where the most complete sequence was recorded, was deposited in a more subsident and quieter setting $[25,89]$.

\subsection{Morocco Hosting the Largest Phosphate Reserves}

Phosphate reserves are dynamic and changeable over time, depending on several factors, including production rates, the discovery of new reserves, and the reclassification of resources and reserves $[9,109]$. Currently, there are several sources of publicly available global inventory data on resources/reserves and the production and consumption of phosphates. These data are commonly reported every year by the major geological surveys (e.g., USGS, WMD, BGS, etc.) [110]. In fact, the most comprehensive study on phosphate reserves and resources remains that of Steven Van Kauwenbergh in 2010 [111], which summarizes the results of several previous studies, showing that the estimates of reserves range from 15,000 MMT (Million Metric Tons) to over 1,000,000 MMT, while resource estimates range from $~ 91,000$ MMT to over 1,000,000 MMT. However, the only major geological survey providing up-to-date data regarding global phosphate rock reserves is the USGS, which shows that the current global resources of phosphate rock are more than 300,000 billion tons, and the reserves are of 71,000 MMT [17]. Morocco holds the largest reserves in the world, with 70-75\% (approximately 50,000 MMT) of the total world's known phosphate reserves (Figure 9A) [17]. However, these estimated reserves have not 
changed since 2010, while the production has increased over the same period (Figure 9). This situation clearly justifies the need to reevaluate the resources and reserves in Morocco, given their importance on the global market. Either way, the share of Moroccan reserves is expected to increase in the coming decades owing to its relatively high reserve-toproduction ratio compared with other producing countries. While Morocco has the largest reserves, China contributes $40 \%$ of the global production, compared with $17 \%$ for Morocco (Figure 9B). The United States, which was once the largest producer, contributes currently only $11 \%$ to global production. The USA was surpassed by China in 2006 [112], and by Morocco in 2017 (Figure 9C). At the current production rate, Morocco has the highest reserve-to-production ratio, with more than 1300 years, while all other countries do not exceed 200 years of mine production (Figure 9D). However, the reserve-to-production $(\mathrm{R} / \mathrm{P})$ ratio indicates the lifetime of the reserves at current production rates; it does not take into consideration the possible changes and reclassification of reserves and resources [9]. For Morocco, this ratio is expected to decrease, knowing that its production is increasing continually, having increased by 43\% over the past 10 years, from 25,000 MT in 2010 to 37,000 MT in 2020 (Figure 9D).
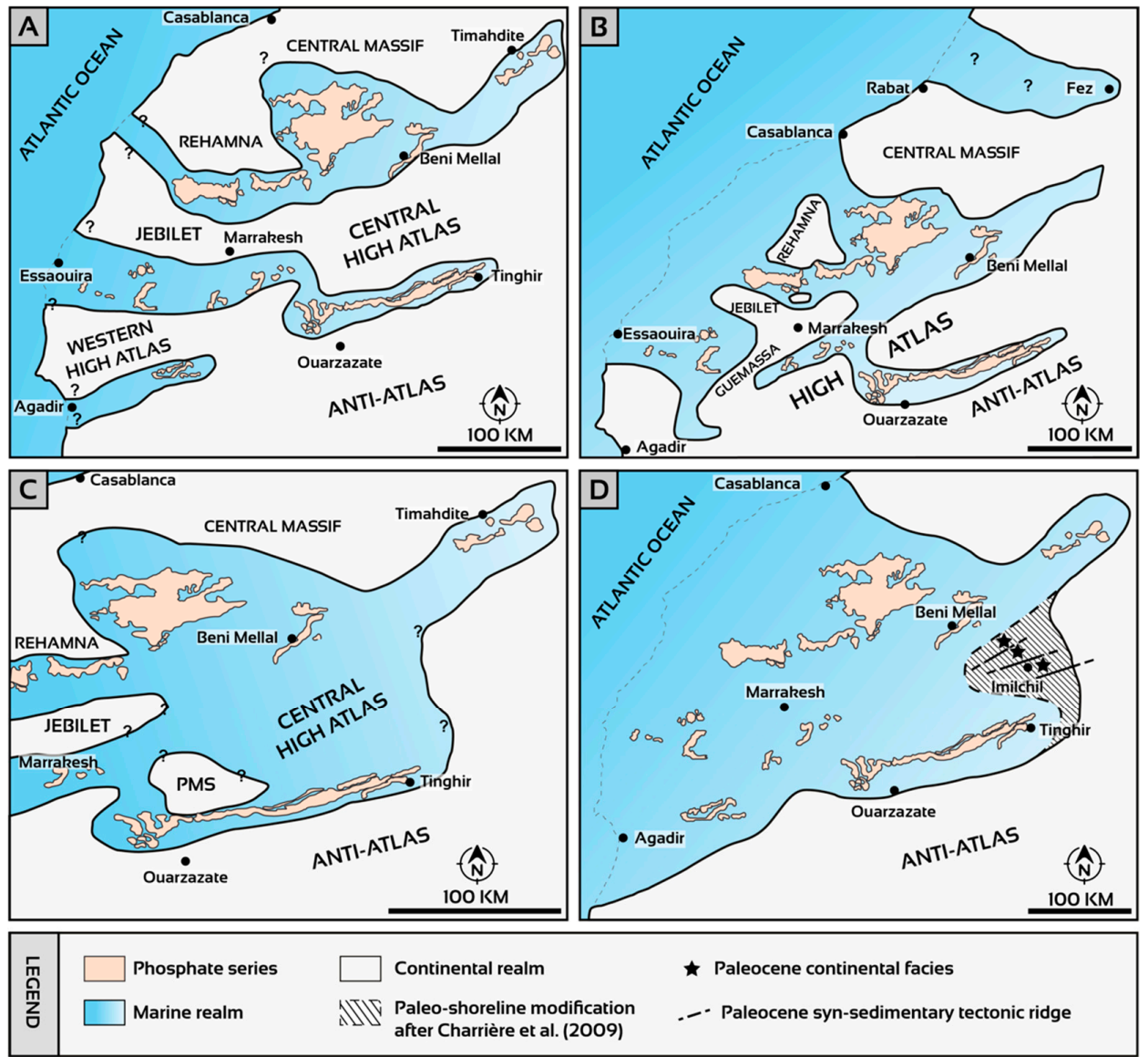

Figure 8. Paleogeographic models of the Moroccan phosphogenic system: (A) Model of several narrow gulfs [89]. (B) Large Atlantic Ocean connection with interconnected gulfs [104]. (C) Model of a single epicontinental sea with the presence of land masses [105,106]; PMS: Paleozoic Massif of Skoura. (D) A single epicontinental sea without land masses [91]. 


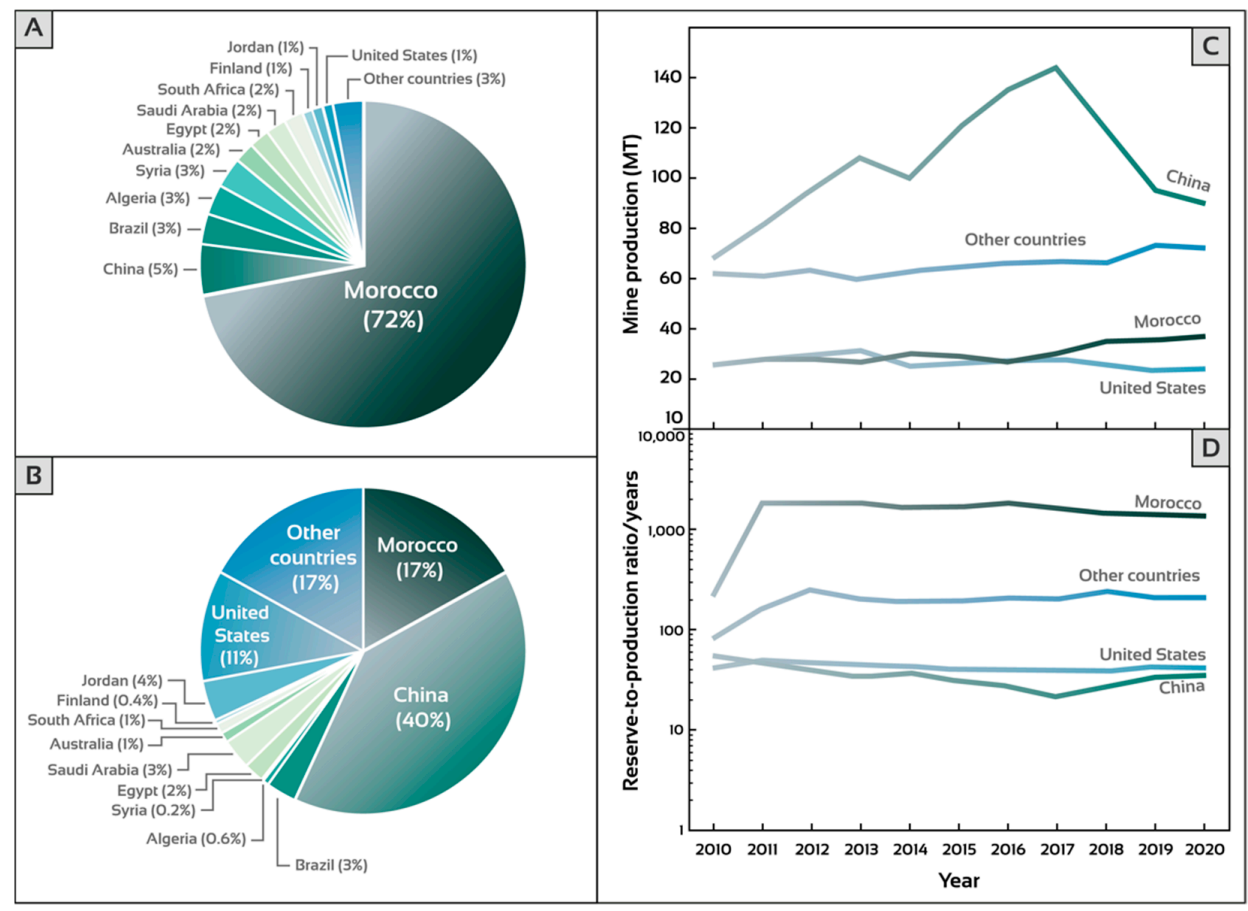

Figure 9. (A) Distribution of phosphate rock reserves. (B) Share of world phosphate rock production in 2020. (C) Mine phosphate production over the past 10 years in major producer countries. (D) Reserve-to-production ratio for the major producer countries.

On the other hand, several estimates using long-term projections over centuries have been proposed for the so-called "phosphorus peak" (Figure 10). This peak, reached when half of the reserves are consumed, is situated between 2025 and 2084 (Figure 10). It should be noted that the dynamic character of phosphate reserves makes these estimates less accurate, but it is evident that Morocco is a major global player in phosphate production. This is especially true owing to the fact that the exploration of phosphates in Morocco still has promising potential, particularly regarding the Moroccan High Atlas phosphate-rich sediments [18] and igneous phosphates.

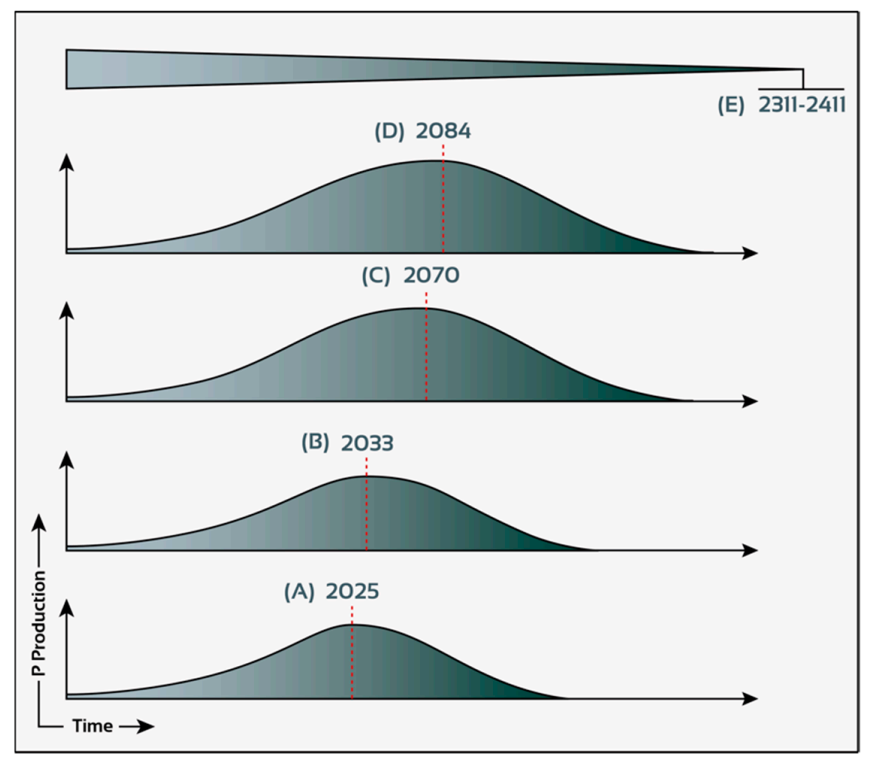

Figure 10. Future projections of phosphate rock production, with different estimates of the so-called phosphorus peak according to: A [113], B [114], C [11], D [115], and E [111]. 


\section{Moroccan Igneous Phosphates: An Underexplored Resource}

Morocco also has several alkaline and carbonatite complexes that remain underexplored in terms of their potential for igneous phosphate resources. The main alkaline and carbonatite complexes capable of harboring this type of mineral deposit are located in three main zones (Figure 11) $[19,21,116,117]$ : (1) the Cenozoic alkaline-carbonatite massif of Tamazeght (High Atlas); (2) the Jurassic-Cretaceous alkaline complex of Imilchil (High Atlas); and (3) the Paleoproterozoic carbonatite intrusions of Gleibat Lafhouda (Dakhla Province).

The Tamazeght Massif is located on the northern edge of the central High Atlas, $20 \mathrm{~km}$ southeast of Midelt (Figure 11A); it forms an elongated elliptical intrusion of $17 \mathrm{~km}$ by $5 \mathrm{~km}$ (area $\sim 70 \mathrm{~km}^{2}$ ) with a NE-SW orientation. This massif includes many magmatic intrusive phases, which show a progression from ultramafic to alkaline/peralkaline felsic rocks $[116,118,119]$. Consequently, a wide lithological range is present, including pyroxenites and gabbroic to monzonitic-syenitic rocks. In addition, several diatremes and dykes of various types - ranging from carbonatite and lamprophyre to phonolite-trachyte-are present within the massif and in its Jurassic country sediments (mostly limestones). Based on structural features, field relationships, and enclaves within different facies, Kchit [120] proposed an increasing chronological order for these magmatic facies: ultramafic rocks (e.g., pyroxenites); shonkinites; monzogabbros; foid-monzosyenites; malignites and pegmatites; nepheline syenites; monzonitic rocks; carbonatites and phonolites-trachytes; lamprophyres. The radiometric age attributed to the Tamazeght massif is Cenozoic ( 45-35 Ma) [116]. Tamazeght carbonatites are generally grouped into two main facies: (1) calcite carbonatites (dominant), and (2) dolomite carbonatites, called calcio- and magnesiocarbonatites, respectively [116]. A subordinate type of carbonatite defined as silicocarbonatite (carbonates $<50 \mathrm{vol} \%$ ) has also been recognized [116]. Calciocarbonatite (calcite $80-90 \mathrm{vol} \%$ ) is composed of varying amounts of apatite (10-20 vol\%), pyrochlore (5-10 vol\%), and titanite (up to $10 \mathrm{vol} \%$ ), accompanied by phlogopite, dolomite, ankerite, albite, K-feldspar, and quartz. On the other hand, the magnesiocarbonatite consists of $>50 \%$ dolomite, up to $10 \%$ calcite, and phlogopite. The non-carbonate phases are apatite, magnetite, amphibole, and quartz, representing $1-5 \mathrm{vol} \%$ of the rock $[116,120]$.

The Imilchil region in the Central High Atlas is a province of numerous magmatic intrusions with alkaline affinity and Jurassic-Cretaceous age ( 165-125 Ma), oriented NE-SW to E-W with an elongated shape (10-40 $\times 1.5-4 \mathrm{~km})$, but also in the form of minor satellite intrusions $(0.5-2 \times 0.5-1 \mathrm{~km})$ (Figure 11B) [121-123]. The gabbro is the dominant facies in these intrusions (60-70 vol\% of the intrusion); it is often associated with monzonitesyenite association bodies, representing the remaining volume of the intrusion. Several of these magmatic structures host gem-quality apatite vein-type ores $[19,124]$. Apatite from these High Atlas deposits is known through the activity of mineral collectors who recover and resell apatite crystals for international mineral markets (Figure 12A) [19,124,125]. The main apatite deposits are spatially associated with differentiated magmatic rocks (especially syenites) $[19,124]$. This mineralization forms $\mathrm{mm}$ to several $\mathrm{cm}$ thick veins without any preferential orientation. Their current exploitation is done only in an artisanal manner, and mainly benefits the mineral collectors. The mineralogical assemblages of gemquality apatite ores (apatite of up to $15 \mathrm{~cm}$ in size and 30\% by volume of the veins) from different localities of High Atlas/Imilchil are slightly variable, while the main components are always alkaline feldspars (albite, $\mathrm{K}$ feldspar), pyroxene, amphibole, quartz, prehnite, calcite, magnetite, epidote, and titanite (Figure 12A) [19,124]. 


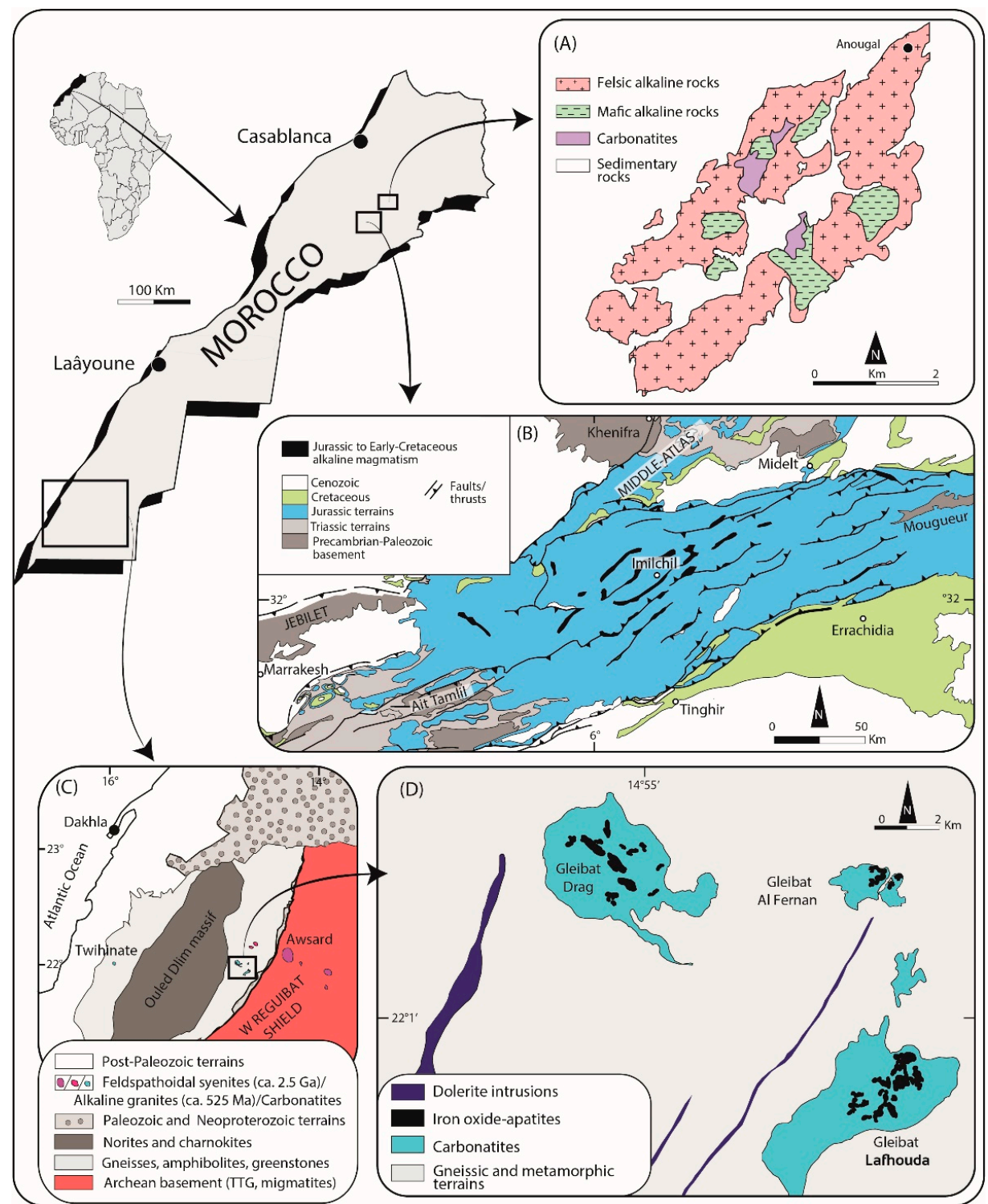

Figure 11. Simplified geological maps of: (A) the Tamazeght alkaline-carbonatite massif (adapted from [120]), (B) the Imilchil alkaline complex (adapted from $[19,126]$ ), (C) geological map of the West Reguibat area showing the main alkaline magmatic occurrences of southern Morocco (adapted from [20,117]), and (D) the Gleibat Lafhouda carbonatite complex (adapted from $[20,117]$ ).
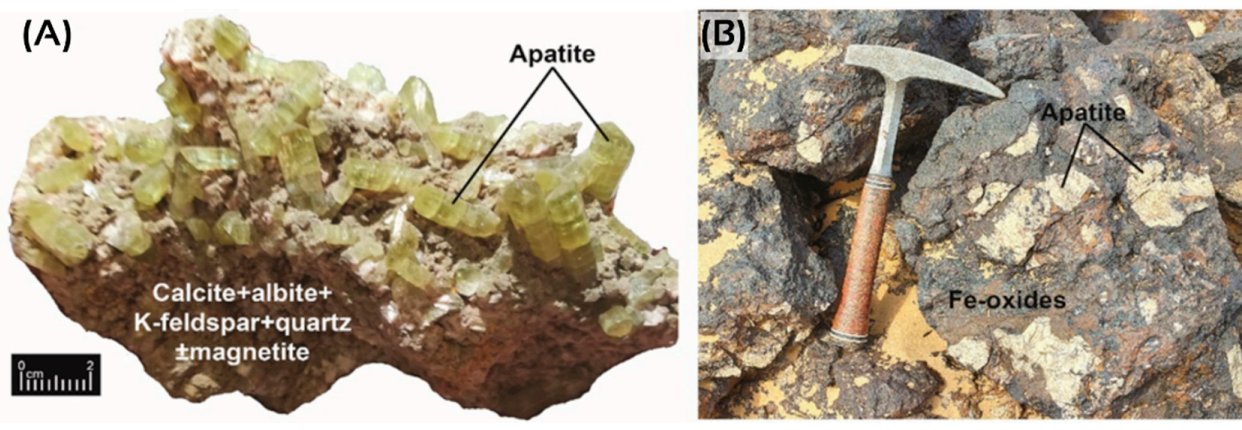

Figure 12. Photographs of the Moroccan apatite ores: (A) High Atlas Imilchil apatite gems [19]. (B) Dakhla Gleibat Lafhouda iron oxide-apatite ore associated with carbonatite complex [20]. 
The western Reguibat of southern Morocco hosts several isolated alkaline and carbonatite complexes, forming the so-called "West Reguibat Alkaline Province" (Figure 11C; e.g., [127,128]. This includes several Cambrian (ca. $525 \mathrm{Ma}$ ) alkaline granitic [129] and ca. 2.5 Ga kalsilite-nepheline syenitic plutons $[127,128]$, as well as numerous carbonatite occurrences [117]. The carbonatites form isolate carbonatite structures, mainly including those of the Gleibat Lafhouda and Twihinate regions (Figure 11C) [22,23,117]. Twihinate carbonatite occurs as a small annular structure (diameter $<5 \mathrm{~km}$ ) composed mostly of silica and iron oxide rocks, with minor calciocarbonatite outcrops attributed to the Cretaceous Age (ca. $104 \mathrm{Ma}$ ) [117]. This small outcropping structure seems to be the cupola of a larger intrusion [117], and its economic potential has not yet been fully explored. Only a few studies have reported the significant REE and $\mathrm{Nb}$ concentrations (REE up to 0.7-3 wt.\% and $\mathrm{Nb}$ up to $0.2-1.3 \mathrm{wt} . \%$ ) associated with the Twihinate structure $[23,117,130]$; however, no research has been devoted to its phosphate resources. In contrast, the well-exposed and widely extending structural outcrop in the Gleibat Lafhouda region (Figure 11C,D) corresponds to an isolated Paleoproterozoic (ca. 1.8 Ga) complex of magnesiocarbonatites, which includes three intrusions (Drag, Al Fernan, and Lafhouda), and could cover a total area of $\sim 300 \mathrm{~km}^{2}$ (Figure 11D) [20,21,117]. Generally, these carbonatites are often covered by a crust of iron oxide-apatite ores (Figure 11D; Figure 12B). The Gleibat Lafhouda magnesiocarbonatites consist of dolomite (70-90\%), apatite (up to 10\%), Fe oxides (mostly magnetite and hematite), and rare calcite [20]. The iron oxide-apatite ores observed at the top of the Gleibat Lafhouda carbonatite intrusions consist mainly of Fe oxides associated with a significant concentration of apatite (up to 40\%) (Figure 12B). In terms of economic potential, the Gleibat Lafhouda ores contain significant concentrations of apatite, either in iron oxide-apatite or in carbonatites, which are sometimes associated with $\mathrm{Nb}$ - and REErich minerals (e.g., ferrocolumbite, monazite) [21]. In addition, these data are supported by the prospective results assessing the significant resources linked to high $\mathrm{P}_{2} \mathrm{O}_{5}$ contents, which can exceed 5-7 wt.\% in carbonatites and $33 \mathrm{wt} . \%$ in iron oxide-apatite rocks [20,117], along with REE and $\mathrm{Nb}$ mineralization (100 million tons with $0.3 \mathrm{wt}$. $\%$ REE and $0.4 \mathrm{wt} . \%$ $\mathrm{Nb}_{2} \mathrm{O}_{5}$ in iron oxide-apatite ores) [21].

Despite the presence of several potential zones for the exploration of igneous phosphate resources in Morocco, the zones cited above are not of the same interest. For the alkaline-carbonatite complex of Tamazeght, given the presence of significant outcrops of carbonatites and alkaline silicate rocks as well as pegmatites, it remains strongly preferred for exploration, knowing that the REE contents could reach $1 \mathrm{wt}$. $\%$ in some sample rocks studied by $[116,118]$. In addition, $\mathrm{P}_{2} \mathrm{O}_{5}$ contents can reach up to $\sim 3 \mathrm{wt} . \%$, especially in carbonatites, and $\sim 1.2-4$ wt. $\% \mathrm{P}_{2} \mathrm{O}_{5}$ in some alkaline silicate rocks $[116,118,131]$. The Imilchil alkaline intrusions of the High Atlas remain interesting for advanced geological exploration in order to understand the geological context of the genesis of gem-quality apatite. Their characterization, as well as the characterization of their host rocks, could reveal potential resources in the future. Likewise, the carbonatites from southern Morocco are still the most suitable areas in terms of igneous phosphate resources and related REE.

\section{Conclusions}

Phosphate rocks of both sedimentary and igneous origin began to form on Earth since the Paleoproterozoic in a myriad of geological environments, and they were preserved in a large number of locations in the world. However, the largest phosphate resources are located in Morocco. All of the mineable and known economic resources in this country are sedimentary marine phosphorites. They were deposited from the Maastrichtian to the Ypresian within wide-extent, tectonically stable marine platforms with diverse subenvironments and an outstanding biological diversity. They are a typical example of all the differentiation processes and pathways that phosphate sediment can undergo. This is reflected by the wide variety of observed lithofacies, showing different sedimentary characteristics and fossil content. However, robust correlations between the different parts of the Moroccan phosphogenic systems are still required in order to provide some clar- 
ifications in terms of paleogeography, and to effectively target the potential phosphatic zones. A reassessment of available resources and reserves according to their quality and exploitability also remains a necessity, given their importance on a global scale. Their exploitation has also become a field in which more sustainable practices should be adopted in order to ensure sufficient production for future generations by introducing innovative ways of mining and beneficiation. Morocco also has potential in terms of igneous phosphates, which still remain to be well explored. The discovery of such resources will position Morocco from afar as being undoubtedly the land of phosphates.

Author Contributions: Conceptualization, R.E.B., O.R., M.O. and A.E.; literature review and data collection, R.E.B., O.R. and M.O.; validation, O.R., M.O., A.E. and J.-L.B.; formal analysis, R.E.B. and O.R.; writing-original draft preparation, R.E.B. and O.R., writing-review and editing, R.E.B., O.R., M.O, A.E. and O.K.Y.; supervision, J.-L.B. All authors have read and agreed to the published version of the manuscript.

Funding: Not applicable.

Data Availability Statement: Not applicable.

Acknowledgments: This paper is a part of an UM6P project aiming to collect and reinterpret data on Moroccan phosphates in comparison to other phosphate rocks worldwide. The authors would like to thank all those who contributed and facilitated this study-in particular from the OCP Group.

Conflicts of Interest: No potential conflict of interest was reported by the authors.

\section{References}

1. Filippelli, G.M. Phosphate Rock Formation and Marine Phosphorus Geochemistry: The Deep Time Perspective. Chemosphere 2011, 84, 759-766. [CrossRef] [PubMed]

2. Pufahl, P.K.; Groat, L.A. Sedimentary and Igneous Phosphate Deposits: Formation and Exploration: An Invited Paper. Econ. Geol. 2017, 112, 483-516. [CrossRef]

3. Emsbo, P.; McLaughlin, P.I.; Breit, G.N.; du Bray, E.A.; Koenig, A.E. Rare Earth Elements in Sedimentary Phosphate Deposits: Solution to the Global REE Crisis? Gondwana Res. 2015, 27, 776-785. [CrossRef]

4. Wu, S.; Wang, L.; Zhao, L.; Zhang, P.; El-Shall, H.; Moudgil, B.; Huang, X.; Zhang, L. Recovery of Rare Earth Elements from Phosphate Rock by Hydrometallurgical Processes-A Critical Review. Chem. Eng. J. 2018, 335, 774-800. [CrossRef]

5. Gabriel, S.; Baschwitz, A.; Mathonnière, G.; Eleouet, T.; Fizaine, F. A Critical Assessment of Global Uranium Resources, Including Uranium in Phosphate Rocks, and the Possible Impact of Uranium Shortages on Nuclear Power Fleets. Ann. Nucl. Energy 2013, 58, 213-220. [CrossRef]

6. Mar, S.S.; Okazaki, M. Investigation of Cd Contents in Several Phosphate Rocks Used for the Production of Fertilizer. Microchem. J. 2012, 104, 17-21. [CrossRef]

7. Menzel, R.G. Uranium, Radium, and Thorium Content in Phosphate Rocks and Their Possible Radiation Hazard. Available online: https:/ / pubs.acs.org/doi/pdf/10.1021/jf60156a002 (accessed on 25 September 2021).

8. Kent, J.A. Phosphorus and Phosphates. In Riegel's Handbook of Industrial Chemistry; Kent, J.A., Ed.; Springer: Boston, MA, USA, 2003; pp. 362-385. ISBN 978-0-387-23816-6.

9. Daneshgar, S.; Callegari, A.; Capodaglio, A.G.; Vaccari, D. The Potential Phosphorus Crisis: Resource Conservation and Possible Escape Technologies: A Review. Resources 2018, 7, 37. [CrossRef]

10. Desmidt, E.; Ghyselbrecht, K.; Zhang, Y.; Pinoy, L.; Van der Bruggen, B.; Verstraete, W.; Rabaey, K.; Meesschaert, B. Global Phosphorus Scarcity and Full-Scale P-Recovery Techniques: A Review. Crit. Rev. Environ. Sci. Technol. 2015, 45, 336-384. [CrossRef]

11. Cordell, D.; White, S. Peak Phosphorus: Clarifying the Key Issues of a Vigorous Debate about Long-Term Phosphorus Security. Sustainability 2011, 3, 2027-2049. [CrossRef]

12. Broom-Fendley, S.; Siegfried, P.R.; Wall, F.; O’Neill, M.; Brooker, R.A.; Fallon, E.K.; Pickles, J.R.; Banks, D.A. The Origin and Composition of Carbonatite-Derived Carbonate-Bearing Fluorapatite Deposits. Min. Depos. 2021, 56, 863-884. [CrossRef]

13. Föllmi, K.B. The Phosphorus Cycle, Phosphogenesis and Marine Phosphate-Rich Deposits. Earth-Sci. Rev. 1996, 40, 55-124. [CrossRef]

14. Piper, D.Z.; Codispoti, L.A. Marine Phosphorite Deposits and the Nitrogen Cycle. Science 1975, 188, 15-18. [CrossRef] [PubMed]

15. Schuffert, J.D.; Kastner, M.; Jahnke, R.A. Carbon and Phosphorus Burial Associated with Modern Phosphorite Formation. Mar. Geol. 1998, 146, 21-31. [CrossRef]

16. Chew, D.M.; Spikings, R.A. Geochronology and Thermochronology Using Apatite: Time and Temperature, Lower Crust to Surface. Elements 2015, 11, 189-194. [CrossRef]

17. Jasinski, S.M. Mineral Commodity Summaries: Phosphate Rock. US Geol. Surv. 2021. 
18. El Bamiki, R.; Séranne, M.; Chellaï, E.H.; Merzeraud, G.; Marzoqi, M.; Melinte-Dobrinescu, M.C. The Moroccan High Atlas Phosphate-Rich Sediments: Unraveling the Accumulation and Differentiation Processes. Sediment. Geol. 2020, $403,105655$. [CrossRef]

19. Ouabid, M.; Raji, O.; Dautria, J.-M.; Bodinier, J.-L.; Parat, F.; El Messbahi, H.; Garrido, C.J.; Ahechach, Y. Petrological and Geochemical Constraints on the Origin of Apatite Ores from Mesozoic Alkaline Intrusive Complexes, Central High-Atlas, Morocco. Ore Geol. Rev. 2021, 136, 104250. [CrossRef]

20. Malainine, C.-E.; Raji, O.; Ouabid, M.; Khouakhi, A.; Bodinier, J.-L.; Laamrani, A.; Messbahi, H.E.; Youbi, N.; Boumehdi, M.A. An Integrated ASTER-Based Approach for Mapping Carbonatite and Iron Oxide-Apatite Deposits. Geocarto Int. $2021,1-19$. [CrossRef]

21. Benaouda, R.; Kraemer, D.; Sitnikova, M.; Goldmann, S.; Freitag, R.; Bouali, A.; Mouttaqi, A.; El Haloui, R.; Essaadaoui, M.; Bau, M. Thorium-Poor Monazite and Columbite-(Fe) Mineralization in the Gleibat Lafhouda Carbonatite and Its Associated Iron-Oxide-Apatite Deposit of the Ouled Dlim Massif, South Morocco. Gondwana Res. 2020, 77, 19-39. [CrossRef]

22. ONHYM Glibat Lafhouda Carbonatites (Southern Provinces, Morocco). 2016. Available online: http://www.onhym.com/pdf/ en/PromotionEn/1_Glibat\%20Lafhouda_2018_Ang.pdf (accessed on 25 September 2021).

23. ONHYM Annular Structure of Twihinate (REE, Nb, Fe, U; Southern Provinces, Morocco) 2016. Available online: http://www. onhym.com/pdf/en/MiningPromotion_2021ENG/02_Twihinate_Lamlaga_2021Eng.pdf (accessed on 25 September 2021).

24. Trappe, J. A Nomenclature System for Granular Phosphate Rocks According to Depositional Texture. Sediment. Geol. 2001, 145, 135-150. [CrossRef]

25. Lucas, J.; Prevot-Lucas, L. On the Genesis of Sedimentary Apatite and Phosphate-Rich Sediments. In Soils and Sediments: Mineralogy and Geochemistry; Paquet, H., Clauer, N., Eds.; Springer: Berlin/Heidelberg, Germany, 1997; pp. 249-268. ISBN 978-3-642-60525-3.

26. Nathan, Y. The Mineralogy and Geochemistry of Phosphorites. In Phosphate Minerals; Nriagu, J.O., Moore, P.B., Eds.; Springer: Berlin/Heidelberg, Germany, 1984; pp. 275-291. ISBN 978-3-642-61736-2.

27. McClellan, G.H.; Kauwenbergh, S.J.V. Mineralogy of Sedimentary Apatites. Geol. Soc. Lond. Spec. Publ. 1990, 52, 23-31. [CrossRef]

28. Dorozhkin, S.V. Nanosized and Nanocrystalline Calcium Orthophosphates. Acta Biomater. 2010, 6, 715-734. [CrossRef]

29. Burnett, W.C.; Roe, K.K.; Piper, D.Z. Upwelling and Phosphorite Formation in the Ocean. In Coastal Upwelling Its Sediment Record: Part A: Responses of the Sedimentary Regime to Present Coastal Upwelling; Suess, E., Thiede, J., Eds.; NATO Conference Series; Springer: Boston, MA, USA, 1983; pp. 377-397. ISBN 978-1-4615-6651-9.

30. Schöllhorn, I.; Houben, A.; Gertsch, B.; Adatte, T.; Alexey, U.; de Kaenel, E.; Spangenberg, J.E.; Janssen, N.; Schwennicke, T.; Föllmi, K.B. Enhanced Upwelling and Phosphorite Formation in the Northeastern Pacific during the Late Oligocene: Depositional Mechanisms, Environmental Conditions, and the Impact of Glacio-Eustacy. GSA Bull. 2020, 132, 687-709. [CrossRef]

31. Ruttenberg, K.C. 8.13-The Global Phosphorus Cycle. In Treatise on Geochemistry; Holland, H.D., Turekian, K.K., Eds.; Pergamon: Oxford, UK, 2003; pp. 585-643. ISBN 978-0-08-043751-4.

32. Lumiste, K.; Mänd, K.; Bailey, J.; Stüeken, E.E.; Paiste, K.; Lang, L.; Sepp, H.; Lepland, A.; Kirsimäe, K. Constraining the Conditions of Phosphogenesis: Stable Isotope and Trace Element Systematics of Recent Namibian Phosphatic Sediments. Geochim. Et Cosmochim. Acta 2021, 302, 141-159. [CrossRef]

33. Diaz, J.; Ingall, E.; Benitez-Nelson, C.; Paterson, D.; de Jonge, M.D.; McNulty, I.; Brandes, J.A. Marine Polyphosphate: A Key Player in Geologic Phosphorus Sequestration. Science 2008, 320, 652-655. [CrossRef]

34. Crosby, C.H.; Bailey, J.V.; Sharma, M. Fossil Evidence of Iron-Oxidizing Chemolithotrophy Linked to Phosphogenesis in the Wake of the Great Oxidation Event. Geology 2014, 42, 1015-1018. [CrossRef]

35. März, C.; Riedinger, N.; Sena, C.; Kasten, S. Phosphorus Dynamics around the Sulphate-Methane Transition in Continental Margin Sediments: Authigenic Apatite and Fe(II) Phosphates. Mar. Geol. 2018, 404, 84-96. [CrossRef]

36. Wan, B.; Yang, P.; Jung, H.; Zhu, M.; Diaz, J.M.; Tang, Y. Iron Oxides Catalyze the Hydrolysis of Polyphosphate and Precipitation of Calcium Phosphate Minerals. Geochim. Et Cosmochim. Acta 2021, 305, 49-65. [CrossRef]

37. Schwid, M.F.; Xiao, S.; Hiatt, E.E.; Fang, Y.; Nolan, M.R. Iron Phosphate in the Ediacaran Doushantuo Formation of South China: A Previously Undocumented Marine Phosphate Sink. Palaeogeogr. Palaeoclimatol. Palaeoecol. 2020, 560, 109993. [CrossRef]

38. Fang, L.; Zeng, W.; Xu, L.; Huang, L.-Z. Green Rusts as a New Solution to Sequester and Stabilize Phosphate in Sediments under Anoxic Conditions and Their Implication for Eutrophication Control. Chem. Eng. J. 2020, 388, 124198. [CrossRef]

39. Refait, P.; Reffass, M.; Landoulsi, J.; Sabot, R.; Jeannin, M. Role of Phosphate Species during the Formation and Transformation of the Fe(II-III) Hydroxycarbonate Green Rust. Colloids Surf. A Physicochem. Eng. Asp. 2007, 299, 29-37. [CrossRef]

40. Jiang, X.-D.; Sun, X.-M.; Chou, Y.-M.; Hein, J.R.; He, G.-W.; Fu, Y.; Li, D.; Liao, J.-L.; Ren, J.-B. Geochemistry and Origins of Carbonate Fluorapatite in Seamount FeMn Crusts from the Pacific Ocean. Mar. Geol. 2020, 423, 106135. [CrossRef]

41. Lusty, P.A.; Hein, J.R.; Josso, P. Formation and Occurrence of Ferromanganese Crusts: Earth's Storehouse for Critical Metals. Elements 2019, 14, 313318. [CrossRef]

42. Hein, J.R.; Conrad, T.; Mizell, K.; Banakar, V.K.; Frey, F.A.; Sager, W.W. Controls on Ferromanganese Crust Composition and Reconnaissance Resource Potential, Ninetyeast Ridge, Indian Ocean. Deep. Sea Res. Part I Oceanogr. Res. Pap. 2016, $110,1-19$. [CrossRef] 
43. Rudmin, M.; Banerjee, S.; Abdullayev, E.; Ruban, A.; Filimonenko, E.; Lyapina, E.; Kashapov, R.; Mazurov, A. Ooidal Ironstones in the Meso-Cenozoic Sequences in Western Siberia: Assessment of Formation Processes and Relationship with Regional and Global Earth Processes. J. Palaeogeogr. 2020, 9, 1. [CrossRef]

44. Todd, S.E.; Pufahl, P.K.; Murphy, J.B.; Taylor, K.G. Sedimentology and Oceanography of Early Ordovician Ironstone, Bell Island, Newfoundland: Ferruginous Seawater and Upwelling in the Rheic Ocean. Sediment. Geol. 2019, 379, 1-15. [CrossRef]

45. Reinhard, C.T.; Planavsky, N.J.; Gill, B.C.; Ozaki, K.; Robbins, L.J.; Lyons, T.W.; Fischer, W.W.; Wang, C.; Cole, D.B.; Konhauser, K.O. Evolution of the Global Phosphorus Cycle. Nature 2017, 541, 386-389. [CrossRef]

46. Jones, C.; Nomosatryo, S.; Crowe, S.A.; Bjerrum, C.J.; Canfield, D.E. Iron Oxides, Divalent Cations, Silica, and the Early Earth Phosphorus Crisis. Geology 2015, 43, 135-138. [CrossRef]

47. Pufahl, P.K.; Grimm, K.A. Coated Phosphate Grains: Proxy for Physical, Chemical, and Ecological Changes in Seawater. Geology 2003, 31, 801-804. [CrossRef]

48. Schuffert, J.D.; Jahnke, R.A.; Kastner, M.; Leather, J.; Sturz, A.; Wing, M.R. Rates of Formation of Modern Phosphorite off Western Mexico. Geochim. Et Cosmochim. Acta 1994, 58, 5001-5010. [CrossRef]

49. Trappe, J. Phanerozoic Phosphorite Depositional Systems: A Dynamic Model for a Sedimentary Resource System; Lecture Notes in Earth Sciences; Springer: Berlin/Heidelberg, Germany, 1998; ISBN 978-3-540-63581-9.

50. Deer, W.A.; Howie, R.A.; Zussman, J. An Introduction to the Rock-Forming Minerals; GeoscienceWorld: McLean, VA, USA, 2013. [CrossRef]

51. Maria Barros de Oliveira, S.; Aparecida Liguori Imbernon, R. Weathering Alteration and Related REE Concentration in the Catalão I Carbonatite Complex, Central Brazil. J. S. Am. Earth Sci. 1998, 11, 379-388. [CrossRef]

52. Dymek, R.F.; Owens, B.E. Petrogenesis of Apatite-Rich Rocks (Nelsonites and Oxide-Apatite Gabbronorites) Associated with Massif Anorthosites. Econ. Geol. 2001, 96, 797-815. [CrossRef]

53. Simandl, G.J.; Paradis, S. Carbonatites: Related Ore Deposits, Resources, Footprint, and Exploration Methods. Appl. Earth Sci. 2018, 127, 123-152. [CrossRef]

54. Krasnova, N.I.; Petrov, T.G.; Balaganskaya, E.G.; Garcia, D.; Moutte, J.; Zaitsev, A.N.; Wall, F. Introduction to Phoscorites: Occurrence, Composition, Nomenclature and Petrogenesis; GeoscienceWorld: McLean, VA, USA, 2004. [CrossRef]

55. Arzamastsev, A.A.; Arzamastseva, L.V.; Zhirova, A.M.; Glaznev, V.N. Model of Formation of the Khibiny-Lovozero Ore-Bearing Volcanic-Plutonic Complex. Geol. Ore Depos. 2013, 55, 341-356. [CrossRef]

56. Zaitsev, A.N.; Terry Williams, C.; Jeffries, T.E.; Strekopytov, S.; Moutte, J.; Ivashchenkova, O.V.; Spratt, J.; Petrov, S.V.; Wall, F.; Seltmann, R.; et al. Rare Earth Elements in Phoscorites and Carbonatites of the Devonian Kola Alkaline Province, Russia: Examples from Kovdor, Khibina, Vuoriyarvi and Turiy Mys Complexes. Ore Geol. Rev. 2014, 61, 204-225. [CrossRef]

57. Kogarko, L. Chemical Composition and Petrogenetic Implications of Apatite in the Khibiny Apatite-Nepheline Deposits (Kola Peninsula). Minerals 2018, 8, 532. [CrossRef]

58. Cerva-Alves, T.; Remus, M.V.D.; Dani, N.; Basei, M.A.S. Integrated Field, Mineralogical and Geochemical Characteristics of Caçapava Do Sul Alvikite and Beforsite Intrusions: A New Ediacaran Carbonatite Complex in Southernmost Brazil. Ore Geol. Rev. 2017, 88, 352-369. [CrossRef]

59. Laznicka, P. Giant Metallic Deposits: Future Sources of Industrial Metals, 2nd ed.; Springer: Berlin/Heidelberg, Germany, 2010; ISBN 978-3-642-12404-4.

60. Xu, C.; Wang, L.; Song, W.; Wu, M. Carbonatites in China: A Review for Genesis and Mineralization. Geosci. Front. 2010, 1, 105-114. [CrossRef]

61. Lai, X.; Yang, X.; Liu, Y.; Yan, Z. Genesis of the Bayan Obo Fe-REE-Nb Deposit: Evidences from Pb-Pb Age and Microanalysis of the H8 Formation in Inner Mongolia, North China Craton. J. Asian Earth Sci. 2016, 120, 87-99. [CrossRef]

62. Castor, S.B. The mountain pass rare-earth carbonatite and associated ultrapotassic rocks, California. Can. Mineral. 2008, 46, 779-806. [CrossRef]

63. Pitawala, A.; Lottermoser, B.G. Petrogenesis of the Eppawala Carbonatites, Sri Lanka: A Cathodoluminescence and Electron Microprobe Study. Mineral. Petrol. 2012, 105, 57-70. [CrossRef]

64. Bühn, B.; Dörr, W.; Brauns, C.M. Petrology and Age of the Otjisazu Carbonatite Complex, Namibia: Implications for the Pre- and Synorogenic Damaran Evolution. J. Afr. Earth Sci. 2001, 32, 1-17. [CrossRef]

65. Bühn, B. The Role of the Volatile Phase for REE and Y Fractionation in Low-Silica Carbonate Magmas: Implications from Natural Carbonatites, Namibia. Mineral. Petrol. 2008, 92, 453-470. [CrossRef]

66. Antonini, P.; Comin-chiaramonti, P.; Gomes, C.B.; Censi, P.; Riffel, B.F.; Yamamoto, E. The Early Proterozoic Carbonatite Complex of Angico Dos Dias, Bahia State, Brazil: Geochemical and Sr-Nd Isotopic Evidence for an Enriched Mantle Origin. Mineral. Mag. 2003, 67, 1039-1057. [CrossRef]

67. O'Brien, H.; Heilimo, E.; Heino, P. Chapter 4.3-The Archean Siilinjärvi Carbonatite Complex. In Mineral Deposits of Finland; Maier, W.D., Lahtinen, R., O’Brien, H., Eds.; Elsevier: Amsterdam, The Netherlands, 2015; pp. 327-343. ISBN 978-0-12-410438-9.

68. Lee, W.-J.; Wyllie, P.J. Processes of Crustal Carbonatite Formation by Liquid Immiscibility and Differentiation, Elucidated by Model Systems. J. Petrol. 1998, 39, 2005-2013. [CrossRef]

69. Bell, K.; Kjarsgaard, B.A.; Simonetti, A. Carbonatites-Into the Twenty-First Century. J. Petrol. 1998, 39, 1839-1845. [CrossRef]

70. Veksler, I.; Lentz, D. Parental Magmas of Plutonic Carbonatites, Carbonate-Silicate Immiscibility and Decarbonation Reactions: Evidence from Melt and Fluid Inclusions. Melt Incl. Plutonic Rocks 2006, 123-150. 
71. Bell, K.; Rukhlov, A.S. Carbonatites from the Kola Alkaline Province: Origin, Evolution and Source Characteristics; GeoscienceWorld: McLean, VA, USA, 2004. [CrossRef]

72. Chakhmouradian, A.R.; Reguir, E.P.; Zaitsev, A.N.; Couëslan, C.; Xu, C.; Kynický, J.; Mumin, A.H.; Yang, P. Apatite in Carbonatitic Rocks: Compositional Variation, Zoning, Element Partitioning and Petrogenetic Significance. Lithos 2017, 274-275, 188-213. [CrossRef]

73. Smith, M.P.; Campbell, L.S.; Kynicky, J. A Review of the Genesis of the World Class Bayan Obo Fe-REE-Nb Deposits, Inner Mongolia, China: Multistage Processes and Outstanding Questions. Ore Geol. Rev. 2015, 64, 459-476. [CrossRef]

74. Migdisov, A.; Williams-Jones, A.E.; Brugger, J.; Caporuscio, F.A. Hydrothermal Transport, Deposition, and Fractionation of the REE: Experimental Data and Thermodynamic Calculations. Chem. Geol. 2016, 439, 13-42. [CrossRef]

75. Prokopyev, I.R.; Doroshkevich, A.G.; Ponomarchuk, A.V.; Sergeev, S.A. Mineralogy, Age and Genesis of Apatite-Dolomite Ores at the Seligdar Apatite Deposit (Central Aldan, Russia). Ore Geol. Rev. 2017, 81, 296-308. [CrossRef]

76. Toledo, M.C.M.D.; Lenharo, S.L.R.; Ferrari, V.C.; Fontan, F.; Parseval, P.D.; Leroy, G. The compositional evolution of apatite in the weathering profile of the Catalão i alkaline-carbonatitic complex, Goias, Brazil. Can. Mineral. 2004, 42, 1139-1158. [CrossRef]

77. Lottermoser, B.G. Rare-Earth Element Mineralisation within the Mt. Weld Carbonatite Laterite, Western Australia. Lithos 1990, 24, 151-167. [CrossRef]

78. Walter, A.-V.; Nahon, D.; Flicoteaux, R.; Girard, J.P.; Melfi, A. Behaviour of Major and Trace Elements and Fractionation of REE under Tropical Weathering of a Typical Apatite-Rich Carbonatite from Brazil. Earth Planet. Sci. Lett. 1995, 136, 591-602. [CrossRef]

79. Flicoteaux, R.; Lucas, J. Weathering of Phosphate Minerals. In Phosphate Minerals; Nriagu, J.O., Moore, P.B., Eds.; Springer: Berlin/Heidelberg, Germany, 1984; pp. 292-317. ISBN 978-3-642-61736-2.

80. Notholt, A.J.G. Phosphorite Resources in the Mediterranean (Tethyan) Phosphogenic Province: A Progress Report. Sci. Géologiques Bull. Et Mémoires 1985, 77, 9-17.

81. Piqué, A. Géologie Du Maroc: Les Domaines Régionaux et Leur Évolution Structurale; Imprimerie el Maarif al Jadida: Rabat, Morocco, 1994.

82. Cappetta, H. Un nouveau genre de Sélacien (Batomorphii, Myliobatiformes) de l'Yprésien des Ouled Abdoun, Maroc. Geobios 1986, 19, 635-640. [CrossRef]

83. Rauscher, R.; Doubinger, J. Les dinokystes du Maestrichtien phosphaté du Maroc. Sci. Géologiques Bull. Et Mémoires 1982, 35, 97-116. [CrossRef]

84. Ollivier-Pierre, M.-F. La microflore du Paléocène et de l'Eocène des séries phosphatées des Ganntour (Maroc). Sci. Géologiques Bull. Et Mémoires 1982, 35, 117-127. [CrossRef]

85. Soncini, M.-J. Three New Dinoflagellate Cysts from the Moroccan Paleocene-Eocene Phosphates. Rev. Palaeobot. Palynol. 1992, 70, 325-338. [CrossRef]

86. Prévôt, L. Géochimie et pétrographie de la formation à phosphate des Ganntour (Maroc): Utilisation pour une explication de la genèse des phosphorites Cretacé-Eocènes. Ph.D. Thesis, Université Louis Pasteur, Strasbourg, France, 1988.

87. Zouhri, S.; Kchikach, A.; Saddiqi, O.; Haïmer, F.Z.E.; Baidder, L.; Michard, A. The Cretaceous-Tertiary Plateaus. In Continental Evolution: The Geology of Morocco; Michard, A., Saddiqi, O., Chalouan, A., de Lamotte, D.F., Eds.; Lecture Notes in Earth Sciences; Springer: Berlin/Heidelberg, Germany, 2008; Volume 116, pp. 331-358. ISBN 978-3-540-77075-6.

88. Belfkira, O. Evolutions Sédimentologiques et Géochimiques de la Série Phosphatée du Maestrichtien des Ouled Abdoun (Maroc). Ph.D Thesis, Université Scientifique et Médicale de Grenoble, Saint-Martin-d'Hères, France, 1980.

89. Boujo, A. Contribution à l'étude géologique du gisement de phosphate crétacé-éocène des Ganntour (Maroc occidental). Sci. Géologiques Bull. Et Mémoires 1976, 43, 1.

90. Jourani, E. Anatomie Séquentielle et Géochimie Des Phosphates de Bouabout (Gisement de Meskala, Maroc): Eléments Pour Un Modèle Génétique. Ph.D. Thesis, Université De Pau et Des Pays De L'Adour, Pau, France, 1988.

91. Trappe, J. Stratigraphy, facies distribution and Paleogeography of the marine Paleogene from the Western High Atlas, Morocco. Neues Jahrb. Geol. Paläontologie. Abh. 1991, 180, 279-321.

92. Chellai, E.H.; Marzoqi, M.; Pascal, A.; Mouflih, M. Stratigraphy and Evolution of Upper Cretaceous-Palaeogene Sedimentary Systems in the Marrakesh High Atlas (Morocco). Comptes Rendus-Acad. Des Sci. Paris Ser. 2 Sci. De La Terre Et Des Planetes Fasc. A 1995, 321, 745 .

93. Marzoqi, M.; Pascal, A.; Chellai, E.H.; Lang, J. Les séquences de depôts sur la rampe carbonatée maastrichtienne-paléogène en bordure nord orientale du Golfe Atlantique dans la région d'Aït-Ourir (Atlas de Marrakech, Maroc). Bull. des Centres de Rech. Explor. -Prod. Elf-Aquitaine Mémoire 1996, 511-520.

94. Nguidi, M.A.; Mouflih, M.; Benbouziane, A.; Kocsis, L.; El Ouariti, S.; El Boukhari, H.; Aquit, M.; Yazami, O.K. Lithofacies Analysis, Sedimentary Dynamics and Genesis of Maastrichtian-Eocene Phosphorites of BouCraa Deposit (Southern Morocco). J. Afr. Earth Sci. 2021, 177, 104161. [CrossRef]

95. Herbig, H.-G. Das Paläogen Am Südrand Zantralen Hohen Atlas Und Mittleren Atlas Marokkos. Stratigraphie, Fazies, Paläogeographie Und Paläotektonik. Berl. Geowiss. Abh. 1991, 135, 1-289.

96. Noubhani, A.; Cappetta, H. Révision Des Rhombodontidae (Neoselachii, Batomorphii) Des Bassins à Phosphate Du Maroc. Palaeovertebrata 1994, 23, 1-49.

97. Marzoqi, M. Les Systèmes Sédimentaires Marins Du Crétacé Terminal-Paleogene Dans l'Atlas de Marrakech et Le Bassin de Ouarzazate. Thèse d'état, Université Cadi Ayyad, Marrakech, Morocco, 2001. 
98. Kocsis, L.; Gheerbrant, E.; Mouflih, M.; Cappetta, H.; Ulianov, A.; Chiaradia, M.; Bardet, N. Gradual Changes in Upwelled Seawater Conditions (Redox, PH) from the Late Cretaceous through Early Paleogene at the Northwest Coast of Africa: Negative Ce Anomaly Trend Recorded in Fossil Bio-Apatite. Chem. Geol. 2016, 421, 44-54. [CrossRef]

99. Kocsis, L.; Ulianov, A.; Mouflih, M.; Khaldoune, F.; Gheerbrant, E. Geochemical Investigation of the Taphonomy, Stratigraphy, and Palaeoecology of the Mammals from the Ouled Abdoun Basin (Paleocene-Eocene of Morocco). Palaeogeogr. Palaeoclimatol. Palaeoecol. 2021, 577, 110523. [CrossRef]

100. Nathan, Y.; Benalioulhaj, N.; Prévôt, L.; Lucas, J. The Geochemistry of Cadmium in the Phosphate-Rich and Organic-Rich Sediments of the Oulad-Abdoun and Timahdit Basins (Morocco). J. Afr. Earth Sci. 1996, 22, 17-27. [CrossRef]

101. McArthur, J.M.; Walsh, J.N. Rare-Earth Geochemistry of Phosphorites. Chem. Geol. 1984, 47, 191-220. [CrossRef]

102. Amine, M.; Asafar, F.; Bilali, L.; Nadifiyine, M. Hydrochloric Acid Leaching Study of Rare Earth Elements from Moroccan Phosphate. J. Chem. 2019, 2019, e4675276. [CrossRef]

103. Moutaouakil, D.; Giresse, P. Petrologie et Environnements Sedimentaires Des Phosphates Mesocenozoiques Du Bassin Des Ouled Abdoun (Maroc). Bull. De La Société Géologique De Fr. 1993, 164, 473-491.

104. Salvan, H. Géologie Des Gîtes Mineraux Marocains, Vol. 3. Phosphates. Notes Et Mémoires Du Serv. Géologique Du Maroc 1986, 276, 392.

105. Herbig, H.-G.; Trappe, J. Stratigraphy of the Subatlas Group (Maastrichtian-Middle Eocene, Morocco). Newsl. Stratigr. 1994, 30, 125-165. [CrossRef]

106. Herbig, H.-G. Lithostratigraphisch-Fazielle Untersuchungen Im Marinen Alttertiär Südlich Des Zentralen Hohen Atlas (Marokko). Berl. Geowiss. abh. Reihe. Geol. Palaeontol 1986, 66, 343-380.

107. Charrière, A.; Haddoumi, H.; Mojon, P.-O.; Ferrière, J.; Cuche, D.; Zili, L. Mise en évidence par charophytes et ostracodes de l'âge Paléocène des dépôts discordants sur les rides anticlinales de la région d'Imilchil (Haut Atlas, Maroc): Conséquences paléogéographiques et structurales. Comptes Rendus Palevol. 2009, 8, 9-19. [CrossRef]

108. Bardet, N.; Gheerbrant, E.; Noubhani, A.; Cappetta, H.; Jouve, S.; Bourdon, E.; Suberbiola, X.P.; Jalil, N.-E.; Vincent, P.; Houssaye, A.; et al. Les Vertébrés Des Phosphates Crétacés-Paléogènes (72, 1-47, 8 Ma) Du Maroc. Mémoire De La Société Géologique De Fr. 2017, 180, 351-452.

109. Scholz, R.W.; Ulrich, A.E.; Eilittä, M.; Roy, A. Sustainable Use of Phosphorus: A Finite Resource. Sci. Total. Environ. 2013, 461-462, 799-803. [CrossRef]

110. Geissler, B.; Steiner, G.; Mew, M.C. Clearing the Fog on Phosphate Rock Data-Uncertainties, Fuzziness, and Misunderstandings. Sci. Total. Environ. 2018, 642, 250-263. [CrossRef]

111. Van Kauwenbergh, S.J. World Phosphate Rock Reserves and Resources; IFDC: Muscle Shoals, AL, USA, 2010.

112. Cooper, J.; Lombardi, R.; Boardman, D.; Carliell-Marquet, C. The Future Distribution and Production of Global Phosphate Rock Reserves. Resour. Conserv. Recycl. 2011, 57, 78-86. [CrossRef]

113. Mohr, S.; Evans, G. Projections of Future Phosphorus Production. Philica 2013, 380.

114. Cordell, D.; Drangert, J.-O.; White, S. The Story of Phosphorus: Global Food Security and Food for Thought. Glob. Environ. Chang. 2009, 19, 292-305. [CrossRef]

115. Walan, P. Modeling of Peak Phosphorus: A Study of Bottlenecks and Implications for Future Production. Master's Thesis, Uppsala University, Uppsala, Sweden, 2013.

116. Bouabdellah, M.; Hoernle, K.; Kchit, A.; Duggen, S.; Hauff, F.; Klügel, A.; Lowry, D.; Beaudoin, G. Petrogenesis of the Eocene Tamazert Continental Carbonatites (Central High Atlas, Morocco): Implications for a Common Source for the Tamazert and Canary and Cape Verde Island Carbonatites. J. Petrol. 2010, 51, 1655-1686. [CrossRef]

117. Montero, P.; Haissen, F.; Mouttaqi, A.; Molina, J.F.; Errami, A.; Sadki, O.; Cambeses, A.; Bea, F. Contrasting SHRIMP U-Pb Zircon Ages of Two Carbonatite Complexes from the Peri-Cratonic Terranes of the Reguibat Shield: Implications for the Lateral Extension of the West African Craton. Gondwana Res. 2016, 38, 238-250. [CrossRef]

118. Bouabdli, A.; Dupuy, C.; Dostal, J. Geochemistry of Mesozoic Alkaline Lamprophyres and Related Rocks from the Tamazert Massif, High Atlas (Morocco). Lithos 1988, 22, 43-58. [CrossRef]

119. Marks, M.A.W.; Schilling, J.; Coulson, I.M.; Wenzel, T.; Markl, G. The Alkaline-Peralkaline Tamazeght Complex, High Atlas Mountains, Morocco: Mineral Chemistry and Petrological Constraints for Derivation from a Compositionally Heterogeneous Mantle Source. J. Petrol. 2008, 49, 1097-1131. [CrossRef]

120. Kchit, A. Le Complexe Plutonique Alcalin Du Tamazert, Haut-Atlas de Midelt (Maroc): Pétrologie et Structurologie. Ph.D. Thesis, Université Toulouse III, Toulouse, France, 1990.

121. Armando, G. Intracontinental Alkaline Magmatism: Geology, Petrography, Mineralogy and Geochemistry of the Jebel Hayim Massif (Central High Atlas-Morocco); Université de Lausanne: Lausanne, Sweden, 1999.

122. Lhachmi, A.; Lorand, J.-P.; Fabries, J. Pétrologie de l'intrusion alcaline mésozoïque de la région d'Anemzi, Haut Atlas Central, Maroc. J. Afr. Earth Sci. 2001, 32, 741-764. [CrossRef]

123. Essaifi, A.; Zayane, R. Petrogenesis and Origin of the Upper Jurassic-Lower Cretaceous Magmatism in Central High Atlas (Morocco): Major, Trace Element and Isotopic (Sr-Nd) Constraints. J. Afr. Earth Sci. 2018, 137, 229-245. [CrossRef]

124. Dumańska-Słowik, M.; Wesełucha-Birczyńska, A.; Heflik, W.; Maksymiuk, W.; Sikorska-Jaworowska, M. Organic Inclusions Evidence, Composition, and Cathodoluminescence Behaviour for the Formation Conditions of Fluorapatite from Anemzi (Morocco). J. Raman Spectrosc. 2018, 49, 2008-2020. [CrossRef] 
125. Rakovan, J. Connoisseur's Choice: Fluorapatite, Acushnet Quarry, Bristol County, Massachusetts. Rocks Miner. 2015, 90, 244-259. [CrossRef]

126. Michard, A.; Ibouh, H.; Charrière, A. Syncline-Topped Anticlinal Ridges from the High Atlas: A Moroccan Conundrum, and Inspiring Structures from the Syrian Arc, Israel. Terra Nova 2011, 23, 314-323. [CrossRef]

127. Bea, F.; Montero, P.; Haissen, F.; El Archi, A. 2.46 Ga Kalsilite and Nepheline Syenites from the Awsard Pluton, Reguibat Rise of the West African Craton, Morocco. Generation of Extremely K-Rich Magmas at the Archean-Proterozoic Transition. Precambrian Res. 2013, 224, 242-254. [CrossRef]

128. Bea, F.; Montero, P.; Haissen, F.; Rjimati, E.; Molina, J.F.; Scarrow, J.H. Kalsilite-Bearing Plutonic Rocks: The Deep-Seated Archean Awsard Massif of the Reguibat Rise, South Morocco, West African Craton. Earth-Sci. Rev. 2014, 138, 1-24. [CrossRef]

129. Bea, F.; Montero, P.; Haissen, F.; Molina, J.F.; Michard, A.; Lazaro, C.; Mouttaqi, A.; Errami, A.; Sadki, O. First Evidence for Cambrian Rift-Related Magmatism in the West African Craton Margin: The Derraman Peralkaline Felsic Complex. Gondwana Res. 2016, 36, 423-438. [CrossRef]

130. Benaouda, R.; Kraemer, D.; Sitnikova, M.; Goldmann, S.; Schwarz-Schampera, U.; Errami, A.; Mouttaqi, A.; Bau, M. Discovery of High-Grade REE-Nb-Fe Mineralization Associated with Calciocarbonatite in South Morocco. Ore Geol. Rev. 2020, $124,103631$. [CrossRef]

131. Raji, O.; Ouabid, M.; Bodinier, J.-L.; El Messbahi, H.; Malainine, C.E.; Tabbakh, Z. An Integrated Approach for Rapid Delineation of K-Rich Syenites Suitable as Unconventional Potash Resources. Nat. Resour. Res. 2021, 30, 3219-3239. [CrossRef] 